\title{
REVIEW
}

Open Access

\section{Neuropsychiatric decompensation in adolescents and adults with Phelan- McDermid syndrome: a systematic review of the literature}

\author{
Alexander Kolevzon ${ }^{1,2,3,4,5}$ (D), Elsa Delaby ${ }^{6}$, Elizabeth Berry-Kravis ${ }^{7}$ (D) Joseph D. Buxbaum ${ }^{1,2,4,5,8,9}$ (DD and \\ Catalina Betancur ${ }^{6^{*}}$ (D)
}

\begin{abstract}
Phelan-McDermid syndrome (PMS) is caused by haploinsufficiency of the SHANK3 gene on chromosome 22q13.33 and is characterized by intellectual disability, hypotonia, severe speech impairments, and autism spectrum disorder. Emerging evidence indicates that there are changes over time in the phenotype observed in individuals with PMS, including severe neuropsychiatric symptoms and loss of skills occurring in adolescence and adulthood. To gain further insight into these phenomena and to better understand the long-term course of the disorder, we conducted a systematic literature review and identified 56 PMS cases showing signs of behavioral and neurologic decompensation in adolescence or adulthood (30 females, 25 males, 1 gender unknown). Clinical presentations included features of bipolar disorder, catatonia, psychosis, and loss of skills, occurring at a mean age of 20 years. There were no apparent sex differences in the rates of these disorders except for catatonia, which appeared to be more frequent in females (13 females, 3 males). Reports of individuals with point mutations in SHANK3 exhibiting neuropsychiatric decompensation and loss of skills demonstrate that loss of one copy of SHANK3 is sufficient to cause these manifestations. In the majority of cases, no apparent cause could be identified; in others, symptoms appeared after acute events, such as infections, prolonged or particularly intense seizures, or changes in the individual's environment. Several individuals had a progressive neurological deterioration, including one with juvenile onset metachromatic leukodystrophy, a severe demyelinating disorder caused by recessive mutations in the ARSA gene in 22q13.33. These reports provide insights into treatment options that have proven helpful in some cases, and are reviewed herein. Our survey highlights how little is currently known about neuropsychiatric presentations and loss of skills in PMS and underscores the importance of studying the natural history in individuals with PMS, including both cross-sectional and long-term longitudinal analyses. Clearer delineation of these neuropsychiatric symptoms will contribute to their recognition and prompt management and will also help uncover the underlying biological mechanisms, potentially leading to improved interventions.
\end{abstract}

Keywords: Phelan-McDermid syndrome, SHANK3, 22q13 deletion syndrome, Regression, Bipolar disorder, Catatonia, Psychosis

\footnotetext{
* Correspondence: catalina.betancur@inserm.fr

${ }^{6}$ Sorbonne Université, INSERM, CNRS, Neuroscience Paris Seine, Institut de

Biologie Paris Seine, Paris, France

Full list of author information is available at the end of the article
}

(c) The Author(s). 2019 Open Access This article is distributed under the terms of the Creative Commons Attribution 4.0 International License (http://creativecommons.org/licenses/by/4.0/), which permits unrestricted use, distribution, and reproduction in any medium, provided you give appropriate credit to the original author(s) and the source, provide a link to the Creative Commons license, and indicate if changes were made. The Creative Commons Public Domain Dedication waiver (http://creativecommons.org/publicdomain/zero/1.0/) applies to the data made available in this article, unless otherwise stated. 


\section{Background}

Phelan-McDermid syndrome (PMS, MIM 606232) is a genetic disorder characterized by hypotonia, intellectual disability (ID), severe speech impairments, and autism spectrum disorder (ASD) [1]. Other frequently associated features include seizures, motor deficits, structural brain abnormalities, renal malformations, gastrointestinal problems, and non-specific dysmorphic features. The core neurodevelopmental features of PMS are caused by haploinsufficiency of the SHANK3 gene, resulting from either 22q13.33 deletions encompassing SHANK3 or point mutations of SHANK3 [2-4]. Deletions can be either simple or result from complex rearrangements such as unbalanced translocations or ring chromosome 22.

Although the prevalence of PMS is unknown, chromosome microarray and targeted resequencing of SHANK3 in ASD and ID suggest that up to $0.5-1 \%$ of subjects may show haploinsufficiency at this locus [5-8]. Because of its nonspecific clinical findings, the frequency of PMS is likely underestimated and is expected to increase with the widespread use of higher resolution microarrays and exome and genome sequencing with optimized coverage of SHANK3 [6, 7]. SHANK3 encodes a scaffolding protein that functions at excitatory postsynaptic densities to organize signaling pathways as well as the synaptic cytoskeleton [9]. In this way, the SHANK3 protein plays a critical role in glutamate transmission, synaptic spine dynamics, and, hence, in learning and memory processes.

Although the core neurobehavioral phenotype observed in individuals with PMS, including ID and ASD, has been extensively described (often in children), changes of the phenotype over time have not been well documented. In fact, little is known about the evolution of the neurological and behavioral phenotype across the lifespan, especially from a longitudinal perspective. In order to provide optimal management and follow-up of PMS patients, it will be critical to obtain insights into the natural history of PMS.

In the past few years, an increasing number of case reports described subjects with PMS showing severe regression with cognitive and/or neurological deterioration, bipolar disorder, catatonia, or psychosis arising in adolescence or adulthood [3, 10-12]. Interestingly, similar findings had been described in earlier studies, including in the first two siblings identified with a SHANK3 mutation [2], in a patient with the smallest SHANK3 deletion reported at the time [13], and, more than three decades ago, in individuals with ring chromosome 22 [14-16]. These descriptions converge towards a sudden change in the psychopathological presentation of the patients. The PMS family and advocacy community is also reporting such changes in social media and at family conferences, generating a great deal of concern among caregivers. It should be noted that loss of skills has also been reported to occur in early childhood in some individuals with PMS, particularly in the domains of language and previously acquired motor skills [4, 1720]. The relationship between this early regression and later-onset phenomena is currently unknown. To gain further insight into the later-onset neurobehavioral phenotype of PMS, we conducted an exhaustive, systematic literature review of reports on individuals with PMS with signs of psychiatric decompensation, loss of skills, or sudden behavioral changes occurring in adolescence or adulthood.

\section{Methods}

A systematic literature search was conducted looking for articles, including case reports, describing subjects with PMS showing signs of behavioral or neurologic decompensation, loss of skills, or neuropsychiatric disorders starting in adolescence or adulthood. We made use of both PubMed and Google Scholar, as well as follow-up of references cited in the papers thus identified. All relevant articles published through July 31, 2019, were included. We used different combinations of the terms Phelan-McDermid, 22q13 deletion, SHANK3, or ring chromosome 22, together with loss of skills/interest/abilities, regression, decline, deterioration, decompensation, catatonia, bipolar, unipolar, depression, mood swings, cyclical, hyperactivity, insomnia, manic, aggressive/aggression, outburst, tantrum, anxiety, withdrawal, apathy, agitation, oscillation, incontinence, dementia, psychosis, hallucination, and adolescent/adolescence or adult. We excluded reviews and case series that did not provide data on individual patients. To distinguish from early childhood regression, we focused on cases where the change in phenotype occurred in adolescence or adulthood.

\section{Results}

Fifty-six cases were identified using our literature search strategy; the findings are shown in Table 1. There were 30 females and 25 males (1 unknown gender), with a mean age of 29.8 years at the time of the report (SD 12.6; range 12 to 70 years). Four families had two or three affected siblings, including three families with parental germline mosaicism and one with monozygotic twins. Earlier papers focus on subjects with ring chromosome 22, diagnosed with karyotype, before the introduction of fluorescent in situ hybridization (FISH) and later chromosomal microarrays allowed the diagnosis of terminal deletions. Ring chromosome 22 involves loss of the distal part of the long arm of the chromosome, generally involving SHANK3 [3, 21]. More recent papers include individuals with deletions diagnosed with chromosome microarray as well as subjects with 
Table 1 PMS patients with neuropsychiatric decompensation reported in the literature

\begin{tabular}{|c|c|c|c|c|c|c|}
\hline Case & 1 & 2 & 3 & 4 & 5 & 6 \\
\hline Reference & Stewart and Richards (1976) [14] ${ }^{\mathrm{a}}$ & Reeve et al. (1985) [15] & Arinami et al. (1986) [16] ${ }^{b}$ & Millichap (1994) [22] & Sovner et al. (1996) [23] & Kehrer-Sawatzki et al. (1997) [24] \\
\hline Subject & - & - & - & - & - & - \\
\hline $\begin{array}{l}\text { Age when } \\
\text { reported }\end{array}$ & $22 \mathrm{y}$ & $28 \mathrm{y}$ & $27 y$ & $24 y$ & $21 \mathrm{y}$ & $38 y$ \\
\hline Sex & Female & Male & Male & Female & Male & Female \\
\hline $\begin{array}{l}\text { Genetic } \\
\text { abnormality }\end{array}$ & $r(22)$, de novo & $r(22)$ & $r(22)$ & $r(22)$ & $r(22)$ & $r(22)$ \\
\hline $\begin{array}{l}\text { Cognitive deficit, } \\
\text { language, and } \\
\text { behavioral } \\
\text { problems }\end{array}$ & Severe ID, nonverbal, restless & $\begin{array}{l}\text { ID, language limited to a few } \\
\text { words. He lived at home, was } \\
\text { described as pleasant and } \\
\text { interacted well with his family. He } \\
\text { worked in a sheltered workshop. }\end{array}$ & $\begin{array}{l}\text { Profound ID, admitted to an } \\
\text { institution at age } 20 \mathrm{y}\end{array}$ & $\begin{array}{l}\text { Profound ID, nonverbal, } \\
\text { hyperactive, } \\
\text { polyembolokoilomania }\end{array}$ & Severe ID & $\begin{array}{l}\text { Mental development during early } \\
\text { infancy was unremarkable, but } \\
\text { language delay became apparent } \\
\text { at the age of } 4 \mathrm{y} \text {. She achieved } \\
\text { low grades in primary school and } \\
\text { was transferred to a special- } \\
\text { needs school at the age of } 10 \mathrm{y} \text {. }\end{array}$ \\
\hline $\begin{array}{l}\text { Age of onset of } \\
\text { decompensation }\end{array}$ & $18 \mathrm{y}$ & $\sim 24 \mathrm{y}$ & $25 \mathrm{y}$ & $16 y$ & $17 y$ & $15 \mathrm{y}$ \\
\hline $\begin{array}{l}\text { Signs of } \\
\text { decompensation, } \\
\text { course of illless, } \\
\text { and treatment }\end{array}$ & $\begin{array}{l}\text { At the age of } 16 y \text {, the patient } \\
\text { had constant tremors of the head, } \\
\text { shoulders, forearms and hands, } \\
\text { resulting in poor motor } \\
\text { coordination. By age } 18 y \text {, she } \\
\text { became increasingly difficult } \\
\text { to feed, behaviorally dysregulated, } \\
\text { and would scream periodically. } \\
\text { Weight loss, mental, and physical } \\
\text { deterioration led to the need for } \\
\text { permanent care at the age of } 22 y \text {. } \\
\text { There remains posturing of her left } \\
\text { forearm in a permanently flexed } \\
\text { position with ventriflexion of the } \\
\text { wrist. She appeared to have } \\
\text { contractures but no neurological } \\
\text { signs were found. }\end{array}$ & 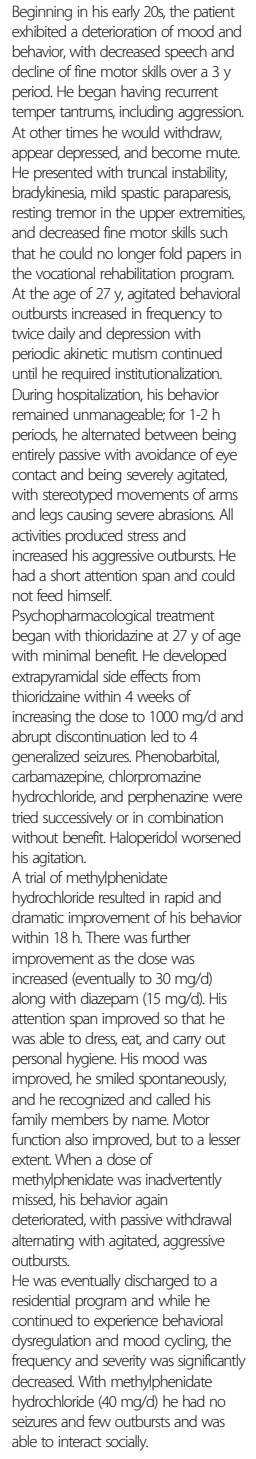 & $\begin{array}{l}\text { At the age of } 25 \mathrm{y} \text {, the patient } \\
\text { exhibited episodes of apathy, } \\
\text { insomnia, anorexia, vomiting, } \\
\text { mask-like facial expression, tremor } \\
\text { of the upper extremities, instability } \\
\text { of gait, and convulsions. These } \\
\text { symptoms worsened and the } \\
\text { patient died at } 27 \text { y of age. } \\
\text { Necropsy revealed the presence of } \\
\text { multifocal meningiomas. The } \\
\text { apparent cause of death was a } \\
\text { subarachnoid cyst with } \\
\text { meningocytic elements at the } \\
\text { medullocerebellar angle that had } \\
\text { compressed the medulla } \\
\text { oblongata and surrounding brain } \\
\text { tissues. } \\
\text { These findings in a subject with } \\
\text { r(22) suggest a diagnosis of } \\
\text { neurofibromatosis } 2 \text { (NF2). At the } \\
\text { age of } 20 \text {, he had no signs of NF2 } \\
\text { on physical exam, although } \\
\text { hearing loss was reported. }\end{array}$ & $\begin{array}{l}\text { At } 16 \text { y of age, the patient was } \\
\text { placed in a residential home } \\
\text { because of aggressive and } \\
\text { destructive behavior, insomnia, } \\
\text { and refusal to eat. Self-injury was } \\
\text { also prominent, with body } \\
\text { bruising and insertion of foreign } \\
\text { ojjects in her nose. Occasional } \\
\text { seizures were also noted and } \\
\text { described as "minor." She often } \\
\text { had a blank stare, and sometimes } \\
\text { appeared catatonic. Behavioral } \\
\text { modification and use of signs for } \\
\text { communication led to } \\
\text { improvement. }\end{array}$ & $\begin{array}{l}\text { At age } 17 \text {, the patient began to } \\
\text { experience cyclical behavioral } \\
\text { dysregulation with refusal to eat } \\
\text { and get out of bed, sleep } \\
\text { maintenance disturbance, } \\
\text { decreased speech, and } \\
\text { tearfulness. } \\
\text { He was stabilized after } \\
\text { approximately } 2 \text { years with what } \\
\text { was described as a "dramatic } \\
\text { response" to fluoxetine ( } 40 \mathrm{mg} \text { / } \\
\text { d), which led to remission of } \\
\text { symptoms. Thirteen months later, } \\
\text { a slow taper of fluoxetine over } 3 \\
\text { months led to a recurrence of } \\
\text { symptoms with anorexia, anxiety, } \\
\text { negativistic behaviors, and self- } \\
\text { injury (hand biting). Fluoxetine } \\
\text { (20 mg/d) was restarted with a } \\
\text { good initial response, but after } 2 \\
\text { months he started to exhibit } \\
\text { rapid cycling }(3 \text { 'bad' days } \\
\text { followed by } 2 \text { 'good' ones). } \\
\text { Divalproex sodium was then } \\
\text { added. Fluoxetine ( } 60 \mathrm{mg} / \mathrm{d}) \text { in } \\
\text { combination with divalproex } \\
\text { sodium (level = } 115 \mu \mathrm{mg} / \mathrm{ml} \text { ) led } \\
\text { to sustained remission of mood } \\
\text { cycling symptoms. }\end{array}$ & $\begin{array}{l}\text { From the age of } 15 \text { y, the patient } \\
\text { exhibited progressive } \\
\text { deterioration of cognitive } \\
\text { function and mood accompanied } \\
\text { by increasing dysarthria. At the } \\
\text { age of } 17 \text { y, she presented with } \\
\text { psychotic symptoms (paranoia; } \\
\text { hallucinations) with frequent } \\
\text { outbursts of aggressive behavior } \\
\text { and required institutionalization. } \\
\text { Since then, she exhibited } \\
\text { parkinsonian symptoms with } \\
\text { repeated akinesia. } \\
\text { At } 38 \text { y, the patient was found to } \\
\text { have several peripheral } \\
\text { neurinomas and CT scan revealed } \\
\text { bilateral vestibular schwannomas, } \\
\text { multiple intracranial } \\
\text { meningiomas. The MRI also } \\
\text { showed an intraspinal tumor } \\
\text { (T12) and an Arnold-Chiari type } 1 \\
\text { malformation. She was diagnosed } \\
\text { with neurofibromatosis type } 2 \\
\text { (related to ring } 22 \text { ) and had } \\
\text { neurosurgery at } 38 \text { y for excision } \\
\text { of infratentorial tumors, a } \\
\text { meningioma and a neurinoma. } \\
\text { A } 5 \text {-y CT follow-up showed only } \\
\text { slight progression of the multiple } \\
\text { supra- and infra-tentorial tumors. } \\
\text { However, the frequency of } \\
\text { seizures increased and she } \\
\text { developed tetraparesis mainly } \\
\text { affecting the lower extremities. }\end{array}$ \\
\hline $\begin{array}{l}\text { Proposed } \\
\text { diagnosis on } \\
\text { review }^{c}\end{array}$ & Unspecified catatonia & Bipolar disorder with catatonia & $\begin{array}{l}\text { Bipolar disorder with catatonia, } \\
\text { NF2 }\end{array}$ & Bipolar disorder with catatonia & Bipolar disorder & $\begin{array}{l}\text { Unspecified psychotic disorder, } \\
\text { NF2 }\end{array}$ \\
\hline Loss of skills ${ }^{d}$ & $+(M, A, C)$ & $+(L, M, A)$ & $+(M)$ & & & $+(M, C)$ \\
\hline $\begin{array}{l}\text { Other } \\
\text { information }\end{array}$ & & $\begin{array}{l}\text { Cranial } C T \text { scan at } 27 \text { y: diffuse } \\
\text { mild cortical atrophy and } \\
\text { hydrocephalus ex vacuo }\end{array}$ & & $\begin{array}{l}\text { Minor partial seizures controlled } \\
\text { with phenytoin up to } 9 \mathrm{y} \text {. Normal } \\
\text { CT scan. }\end{array}$ & & \\
\hline
\end{tabular}


Table 1 PMS patients with neuropsychiatric decompensation reported in the literature (Continued)

\begin{tabular}{|c|c|c|c|c|c|c|}
\hline Case & 7 & 8 & 9 & 10 & 11 & 12 \\
\hline Reference & Anderlid et al. (2002) [13] ${ }^{e}$ & Ishmael et al. (2003) [25] & Ishmael et al. (2003) [25] & Ishmael et al. (2003) [25] & Tsilchorozidou et al. (2004) [26] & Nawab et al. (2007) [27] \\
\hline Subject & - & Subject 1 & Subject 2 & Subject 5 & Case 2 & - \\
\hline $\begin{array}{l}\text { Age when } \\
\text { reported }\end{array}$ & $33 y$ & $12 y$ & $35 y$ & $16 y$ & $52 y$ & $35 y$ \\
\hline Sex & Female & Male & Male & Male & Female & Male \\
\hline $\begin{array}{l}\text { Genetic } \\
\text { abnormality }\end{array}$ & $\begin{array}{l}100 \mathrm{~kb} \text { terminal } 22 \mathrm{q} 13 \text { deletion } \\
\text { including SHANK3, not maternal }\end{array}$ & $r(22)(p 11.2 ; q 13)$, de novo & $\begin{array}{l}\text { r(22) (p11.2; } 1313), 80 \% \text { of } \\
\text { lymphocytes studied showed r(22) }\end{array}$ & $r(22)(p 12 ; q 13)$ & $\begin{array}{l}\text { 46,XX,r(22).ish } \\
\mathrm{r}(22)(\mathrm{p} 11 \mathrm{q} 13)(\mathrm{TUPLE} 1+, 10 \mathrm{H} 11+ \\
\mathrm{ARSA}-(47) / 45, \mathrm{XX},-22(3)\end{array}$ & $r(22)$ \\
\hline $\begin{array}{l}\text { Cognitive deficit, } \\
\text { language, and } \\
\text { behavioral } \\
\text { problems }\end{array}$ & $\begin{array}{l}\text { Mild ID, speech delay, concentration } \\
\text { difficulties at school required remedial } \\
\text { education }\end{array}$ & $\begin{array}{l}\text { ID, developmental regression after } \\
\text { a febrile seizure at } 18 \mathrm{~m} \text {; speech } \\
\text { regression (2-word sentences at } 2 \\
\text { y to a few words at } 5 \mathrm{y} \text { ) }\end{array}$ & ID, nonverbal & ID, nonverbal & Severe ID, nonverbal & $\begin{array}{l}\text { Severe ID, nonverbal. Long term } \\
\text { residential care since the age of } \\
10 \mathrm{y} .\end{array}$ \\
\hline $\begin{array}{l}\text { Age of onset of } \\
\text { deterioration }\end{array}$ & $\sim 25 \mathrm{y}$ & $12 y$ & Teenage years & $12 y$ & 51 y & $23 y$ \\
\hline $\begin{array}{l}\text { Signs of } \\
\text { decompensation, } \\
\text { course of illness, } \\
\text { and treatment }\end{array}$ & $\begin{array}{l}\text { At } 14 \text { y of age the patient was } \\
\text { hospitalized due to an acute } \\
\text { confusional state and diagnosed with } \\
\text { epilepsy. During medication titration } \\
\text { she had aggressive outbursts and her } \\
\text { personality changed. } \\
\text { In her twenties, the symptom severity } \\
\text { progressed, and she exhibited loss of } \\
\text { skills. By age } 30 \text {, she showed features of } \\
\text { autism spectrum disorder with lack of } \\
\text { eye contact, stereotypic movements, } \\
\text { and reduced expressive language. Her } \\
\text { ability to perform daily living activities } \\
\text { deteriorated and she also had balance } \\
\text { problems, ataxic gait and urinary } \\
\text { incontinence. }\end{array}$ & $\begin{array}{l}\text { At } 12 \text { y of age, the patient } \\
\text { showed significant behavioral } \\
\text { changes and no meaningful } \\
\text { speech. He became destructive at } \\
\text { home, breaking objects in the } \\
\text { house during outbursts. } \\
\text { Psychiatric evaluation was } \\
\text { performed and he was diagnosed } \\
\text { with bipolar disorder and treated. }\end{array}$ & $\begin{array}{l}\text { The patient had a history of } \\
\text { behavioral problems beginning in } \\
\text { early childhood that led to } \\
\text { increased aggression and } \\
\text { hyperactivity as he became older. }\end{array}$ & $\begin{array}{l}\text { At } 12 \text { y of age, the patient had an } \\
\text { episode of status epilepticus } \\
\text { followeded by chronic seizures } \\
\text { requiring antiepileptic therapy. } \\
\text { Mental and physical } \\
\text { decompensation ensued. He } \\
\text { developed sensorimotor } \\
\text { polyneuropathy demonstrated on } \\
\text { nerve conduction and } \\
\text { electromyographic studies. Brain } \\
\text { MRl showed diffuse cerebral and } \\
\text { cerebellar atrophy. Leukocyte } \\
\text { arylsulfatase A (ARSA) levels were } \\
\text { low, suggesting juvenile onset } \\
\text { metachromatic leukodystrophy; } \\
\text { however, molecular confirmation } \\
\text { of ARSA deficiency was not done. }\end{array}$ & $\begin{array}{l}\text { The patient developed } \\
\text { generalized seizures at } 51 \text { y ( } 3 \\
\text { seizures per year). She had } \\
\text { pronounced cyclical mood } \\
\text { swings. At age } 52 \text { y, she had } \\
\text { posturing suggestive of catatonia. } \\
\text { CT revealed multiple intracranial } \\
\text { meningiomas and cerebral } \\
\text { atrophy. She was diagnosed with } \\
\text { neurofibromatosis 2, related to } \\
\text { her ring } 22 \text {. } \\
\text { As expected, mutation analysis of } \\
\text { the NF2 gene in blood DNA was } \\
\text { negative. There were no } \\
\text { cutaneous signs of } \\
\text { neurofibromatosis and no } \\
\text { indication for surgical treatment. } \\
\text { She developed status epilepticus } \\
\text { and probable aspiration } \\
\text { pneumonia, and died shortly } \\
\text { after the diagnosis was } \\
\text { established. }\end{array}$ & $\begin{array}{l}\text { The patient displayed cyclical } \\
\text { changes in behavior with } \\
\text { alternating mood shifts between } \\
\text { mania and depression. Cycle } \\
\text { duration varied and could occur in } \\
\text { mixed state or change on a daily } \\
\text { basis. During the manic phases he } \\
\text { made noises, screamed and } \\
\text { laughed inappropriately, was } \\
\text { hyperactive, showed poor } \\
\text { concentration especiallly while } \\
\text { eating, and was unable to feed } \\
\text { himself. He also had reduced need } \\
\text { for sleep. During the depressed } \\
\text { phases, he was lethargic, didn't eat } \\
\text { properly, and exhibited motor } \\
\text { retardation, apathy, and social } \\
\text { avoidance. The intensity of } \\
\text { symptoms worsened between age } \\
23 \text { y and age } 35 \text { y and his physical } \\
\text { abilities also deteriorated. At } 35 \text { y, } \\
\text { he was wheelchair bound. At this } \\
\text { time, he was diagnosed with rapid } \\
\text { cycling bipolar disorder. } \\
\text { He had been initially treated with } \\
\text { haloperidol with no benefit. } \\
\text { Carbamazepine resulted in some } \\
\text { improvement characterized by } \\
\text { longer periods of cycling. This } \\
\text { improvement was augmented by } \\
\text { quetiapine but the effects were } \\
\text { brief. Olanzapine was then used as } \\
\text { an alternative but without benefit. } \\
\text { Divalproex sodium eventually } \\
\text { resulted in marked improvement. }\end{array}$ \\
\hline $\begin{array}{l}\text { Proposed } \\
\text { diagnosis on } \\
\text { review }^{c}\end{array}$ & Unspecified catatonia & Bipolar disorder & Unspecified mood disorder & Metachromatic leukodystrophy & $\begin{array}{l}\text { Bipolar disorder with catatonia, } \\
\text { NF2 }\end{array}$ & $\begin{array}{l}\text { Bipolar disorder with unspecified } \\
\text { decompensation }\end{array}$ \\
\hline Loss of skills ${ }^{d}$ & $+(L, M, A)$ & & & $+(C)$ & & $+(M, A)$ \\
\hline $\begin{array}{l}\text { Other } \\
\text { information }\end{array}$ & $\begin{array}{l}\text { Brain } C T \text { scan at } 14 \mathrm{y} \text { and MRI at } 30 \mathrm{y} \\
\text { both normal }\end{array}$ & $\begin{array}{l}\text { Brain MRI at } 18 \text { months: } \\
\text { prominent cisterna magna and } \\
\text { mild cerebellar "atrophy"; at } 12 \text { y: } \\
\text { giant cisterna magna and mild } \\
\text { cerebellar "atrophy" (likely } \\
\text { congenital cerebellar hypoplasia) }\end{array}$ & & & & \\
\hline
\end{tabular}


Table 1 PMS patients with neuropsychiatric decompensation reported in the literature (Continued)

\begin{tabular}{|c|c|c|c|c|c|c|}
\hline Case & 13 & 14 & 15 & 16 & 17 & 18 \\
\hline Reference & Durand et al. (2007) [2] & Durand et al. (2007) [2] & Gauthier et al. (2010) [28] & Gauthier et al. (2010) [28] & Gauthier et al. (2010) [28] & Gauthier et al. (2010) [28] \\
\hline Subject & Family ASD 2 (eldest brother) & Family ASD 2 (youngest brother) & $\begin{array}{l}\text { Family PED 419, subject II-1 (eldest } \\
\text { brother) }\end{array}$ & $\begin{array}{l}\text { Family PED } 419 \text {, subject II-2 } \\
\text { (middle brother) }\end{array}$ & $\begin{array}{l}\text { Family PED 419, subject II-3 } \\
\text { (youngest brother) }\end{array}$ & S00161 \\
\hline $\begin{array}{l}\text { Age when } \\
\text { reported }\end{array}$ & $20 \mathrm{y}$ & $20 y$ & NA & NA & NA & $23 y$ \\
\hline Sex & Male & Male & Male & Male & Male & Female \\
\hline $\begin{array}{l}\text { Genetic } \\
\text { abnormality }\end{array}$ & $\begin{array}{l}\text { SHANK3 frameshift mutation (NM_ } \\
\text { 033517.1:c.3679dupG, } \\
\text { p.Ala1227Glyfs*69), de novo (germline } \\
\text { mosaicism) }\end{array}$ & $\begin{array}{l}\text { SHANK3 frameshift mutation (NM_ } \\
\text { 033517.1:..3679dupG, } \\
\text { p.Ala1227Glyfs*69), de novo } \\
\text { (germline mosaicism) }\end{array}$ & $\begin{array}{l}\text { SHANK3 nonsense mutation (NM_- } \\
\text { 033517.1: c.3349C>T, p.Arg1117*), } \\
\text { de novo (germline mosaicism) }\end{array}$ & $\begin{array}{l}\text { SHANK3 nonsense mutation }\left(\mathrm{NM}_{-}\right. \\
\text {033517.1:..3349C>T, p.Arg1117*) } \\
\text { de novo (germline mosaicism) }\end{array}$ & $\begin{array}{l}\text { SHANK3 nonsense mutation } \\
\text { (NM_033517.1: C.3349C }>\text {, } \\
\text { p.Arg } 1117^{*} \text { ), de novo (germline } \\
\text { mosaicism) }\end{array}$ & $\begin{array}{l}\text { SHANK3 missense mutation (NM_- } \\
\text { 033517.1:c.1606C>T, p.Arg536Trp) } \\
\text { R536W, de novo }\end{array}$ \\
\hline $\begin{array}{l}\text { Cognitive deficit, } \\
\text { language, and } \\
\text { behavioral } \\
\text { problems }\end{array}$ & $\begin{array}{l}\text { ID, autism, language limited to some } \\
\text { words and short sentences }\end{array}$ & Severe ID, autism, nonverbal & $\begin{array}{l}\text { Borderline ID (IQ 72); graduated } \\
\text { from high school in a special } \\
\text { educational program for children } \\
\text { with intellectual difficulties. No } \\
\text { autistic features. }\end{array}$ & Mild ID, hyperactivity in childhood & $\begin{array}{l}\text { Moderate ID (IQ 36); attended } \\
\text { education institutions for children } \\
\text { with intellectual deficits }\end{array}$ & $\begin{array}{l}\text { Borderline ID (IQ 73), speech } \\
\text { impairment, poor academic and } \\
\text { social performance. No ASD traits. }\end{array}$ \\
\hline $\begin{array}{l}\text { Age of onset of } \\
\text { deterioration }\end{array}$ & $20 \mathrm{y}$ & $16 y$ & $19 y$ & $21 \mathrm{y}$ & $16 y$ & $11 y$ \\
\hline $\begin{array}{l}\text { Signs of } \\
\text { decompensation, } \\
\text { course of illness, } \\
\text { and treatment }\end{array}$ & $\begin{array}{l}\text { After moving to a new residential } \\
\text { program at } 20 \text { y of age, aggressive } \\
\text { outbursts began with significant loss of } \\
\text { skills, including language and toileting. } \\
\text { He also developed anorexia and } \\
\text { marked weight loss. } \\
\text { At } 23 \text { y, the patient had a seizure- } \\
\text { induced aspiration, was hospitalized, } \\
\text { and died within a few days. }\end{array}$ & $\begin{array}{l}\text { At } 16 y \text { of age, the patient had an } \\
\text { ppisode of aspiration with loss of } \\
\text { consciousness, which necessitated } \\
\text { hospitalization. After moving to a } \\
\text { new residential program at } 16 y \text {, loss } \\
\text { of skills was noted in autonomy and } \\
\text { toileting. He also developed weight } \\
\text { loss. At } 17 \text { y of age, he developed } \\
\text { epilepsy and was started on } \\
\text { clonazepam. A second episode of } \\
\text { aspiration occurred at the age of } 20 \mathrm{y} \text {. } \\
\text { since then, he required a special diet } \\
\text { with soft foods and no liquids. } \\
\text { The patient died a few years later, } \\
\text { after further behavioral } \\
\text { decompensation. }\end{array}$ & $\begin{array}{l}\text { Diagnosed with schizoaffective } \\
\text { disorder }\end{array}$ & Diagnosed with schizophrenia & Diagnosed with schizophrenia & $\begin{array}{l}\text { Diagnosed with schizoaffective } \\
\text { disorder }\end{array}$ \\
\hline $\begin{array}{l}\text { Proposed } \\
\text { diagnosis on } \\
\text { review }^{c}\end{array}$ & Unspecified decompensation & Unspecified decompensation & Schizoaffective disorder & Schizophrenia & Schizophrenia & Schizoaffective disorder \\
\hline Loss of skills ${ }^{d}$ & $+(L, A)$ & $+(A)$ & & & & \\
\hline $\begin{array}{l}\text { Other } \\
\text { information }\end{array}$ & & & & One seizure at age $10 \mathrm{y}$. & & \\
\hline
\end{tabular}


Table 1 PMS patients with neuropsychiatric decompensation reported in the literature (Continued)

\begin{tabular}{|c|c|c|c|c|c|c|}
\hline Case & 19 & 20 & 21 & 22 & 23 & 24 \\
\hline Reference & Pasini et al. (2010) [29] & Bonaglia et al. (2011) [3] & Bonaglia et al. (2011) [3] & Willemsen et al. (2011) [30] & $\begin{array}{l}\text { Verhoeven et al. (2012) [31], } \\
\text { Egger et al. (2016) [32] }]^{\mathrm{f}}\end{array}$ & $\begin{array}{l}\text { Verhoeven et al. (2012) [31], } \\
\text { Egger et al. (2016) [32] }{ }^{9}\end{array}$ \\
\hline Subject & - & Subject P10 & Subject P30 & Patient 7 & $\begin{array}{l}\text { Patient } 1 \text { (younger brother) } \\
\text { (Verhoeven), Patient } 6 \text { (Egger) }\end{array}$ & $\begin{array}{l}\text { Patient } 2 \text { (older brother) } \\
\text { (Verhoeven), Patient } 5 \text { (Egger) }\end{array}$ \\
\hline $\begin{array}{l}\text { Age when } \\
\text { reported }\end{array}$ & $18 \mathrm{y}$ & $40 y$ & $40 \mathrm{y}$ & $48 y$ & $29 \mathrm{y}$ & $31 \mathrm{y}$ \\
\hline Sex & Female & Female & Female & Male & Male & Male \\
\hline $\begin{array}{l}\text { Genetic } \\
\text { abnormality }\end{array}$ & $\begin{array}{l}\mathrm{r}(22) \text { with } 1 \mathrm{Mb} \text { duplication of } 22 \mathrm{q} 13.33 \\
\text { and } 600 \mathrm{~kb} \text { terminal } 22 \mathrm{q} 13.33 \text { deletion, } \\
\text { de novo }\end{array}$ & $\begin{array}{l}8.1 \mathrm{Mb} \text { terminal } 22 \mathrm{q} 13 \text { deletion, } \\
\text { de novo }\end{array}$ & 3.4 Mb terminal $22 \mathrm{q} 13$ deletion & 1.8 Mb terminal $22 \mathrm{q} 13$ deletion & $\begin{array}{l}2.15 \mathrm{Mb} \text { terminal } 22 \mathrm{q} 13 \text { deletion, } \\
\text { de novo (germline mosaicism) }\end{array}$ & $\begin{array}{l}2.15 \text { Mb terminal } 22 q 13 \text { deletion, } \\
\text { de novo (germline mosaicism) }\end{array}$ \\
\hline $\begin{array}{l}\text { Cognitive deficit, } \\
\text { language, and } \\
\text { behavioral } \\
\text { problems }\end{array}$ & $\begin{array}{l}\text { Severe ID, language limited to a few } \\
\text { words, autistic-like behavior }\end{array}$ & $\begin{array}{l}\text { Severe ID, nonverbal. Lived in an } \\
\text { institution for the cognitively } \\
\text { impaired }\end{array}$ & Severe ID, poor speech & $\begin{array}{l}\text { Severe ID, no speech, good social } \\
\text { interaction }\end{array}$ & $\begin{array}{l}\text { Severe ID, severe speech deficit } \\
\text { (virtually absent speech, single } \\
\text { words only), mild features of ASD } \\
\text { including obsessive behaviors, } \\
\text { sleep disturbances, hyperactive } \\
\text { behaviors with temper tantrums }\end{array}$ & $\begin{array}{l}\text { Severe ID, moderately impaired } \\
\text { development of speech and } \\
\text { language (poor articulation, } \\
\text { simple sentences), good social } \\
\text { interaction, episodes of } \\
\text { aggressive behavior }\end{array}$ \\
\hline $\begin{array}{l}\text { Age of onset of } \\
\text { deterioration }\end{array}$ & $17 y$ & $39 y$ & $39 y$ & $45 y$ & $17 y$ & $27 y$ \\
\hline $\begin{array}{l}\text { Signs of } \\
\text { decompensation, } \\
\text { course of illness, } \\
\text { and treatment }\end{array}$ & $\begin{array}{l}\text { At the age of } 17 \mathrm{y} \text {, the patient } \\
\text { developed intense psychomotor } \\
\text { agitation, severe anxiety, aggressive } \\
\text { behavior, and insomnia. Her clinical } \\
\text { course of illness was characterized by } \\
\text { periods of mood cycling, hyperactivity, } \\
\text { and self-injury. } \\
\text { Treatment with both benzodiazepines } \\
\text { and haloperidol was unsuccessful. } \\
\text { Risperidone was titrated rapidly to } 6 \\
\text { mg/d over a } 2 \text {-week period and led to } \\
\text { worsening anxiety, insomnia, and } \\
\text { psychomotor agitation and the dose } \\
\text { was reduced. Symptoms progressively } \\
\text { improved at risperidone } 0.5 \mathrm{mg} \text { twice } \\
\text { daily. After } 6 \text { months of treatment, she } \\
\text { showed no psychomotor agitation, } \\
\text { aggressive behavior, anxiety, or } \\
\text { insomnia. }\end{array}$ & $\begin{array}{l}\text { The patient had her first seizure at } \\
\text { the age of } 3 y \text {, and the second at } \\
\text { the age of } 34 \text { y. At } 39 \text { y, her } \\
\text { seizures became more frequent } \\
\text { and prolonged, despite } \\
\text { antiepileptic treatment. } \\
\text { Neurological evaluation at age } 40 \\
\text { y showed spastic paraparesis, with } \\
\text { upper limbs maintained in a } \\
\text { flexed position and flexed knees. } \\
\text { She also showed decreased } \\
\text { sensitivity to pain and tactile } \\
\text { stimuli. } \\
\text { At age } 43 \text { y, she experienced } \\
\text { rapid motor and cognitive decline } \\
\text { and was no longer able to stand, } \\
\text { walk, or make eye contact. The } \\
\text { spastic tetraparesis also markedly } \\
\text { increased. } \\
\text { Right renal agenesis was } \\
\text { diagnosed during a control } \\
\text { abdominal ultrasound and the } \\
\text { patient died at } 47 y \text { from renal } \\
\text { failure while in a vegetative state. }\end{array}$ & $\begin{array}{l}\text { The patient had long standing } \\
\text { epilepsy (onset at } 5 \text { y). She } \\
\text { experienced a progressive } \\
\text { neurological deterioration } \\
\text { beginning at age } 39 \text { y, with } \\
\text { cortical tremor. }\end{array}$ & $\begin{array}{l}\text { The patient's general functioning } \\
\text { began to markedly decline after a } \\
\text { hospital admission because of } \\
\text { severe pneumonia complicated } \\
\text { by respiratory insufficiency at } 45 \text { y } \\
\text { of age. He was no longer able to } \\
\text { walk, had feeding problems due } \\
\text { to swallowing difficulties, and } \\
\text { became dependent on tube } \\
\text { feeding. His social interaction also } \\
\text { diminished. He developed } \\
\text { seizures. Brain MRI was normal, } \\
\text { except for mild enlargement of } \\
\text { the cisterna magna and central } \\
\text { atrophy. } \\
\text { By } 48 \text { y of age, he was wheelchair } \\
\text { dependent and showed } \\
\text { hypertonia with spastic posture of } \\
\text { the hands and feet. } \\
\text { The patient died from pneumonia } \\
\text { at the age of } 49 \mathrm{y} \text {. }\end{array}$ & 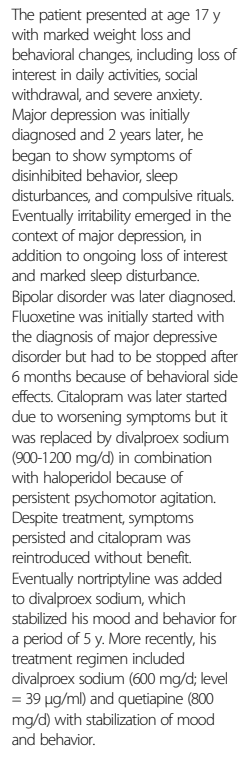 & $\begin{array}{l}\text { The patient first presented at the } \\
\text { age of } 27 \text { y with an unstable } \\
\text { pattern of mood and activity } \\
\text { with recurrent depressive } \\
\text { episodes. } \\
\text { He was diagnosed with atypical } \\
\text { bipolar disorder and treated with } \\
\text { carbamazepine }(400 \mathrm{mg} / \mathrm{d}) \text { and } \\
\text { paroxetine }(30 \mathrm{mg} / \mathrm{d}) \text { with good } \\
\text { effect. This regimen was } \\
\text { eventually replaced by divalproex } \\
\text { sodium (900 } \mathrm{mg} / \mathrm{d} \text {; level }=69 \\
\mu \mathrm{g} / \mathrm{ml} \mathrm{l} \text { ) and quetiapine }(150 \mathrm{mg} / \\
\text { d), which resulted in marked } \\
\text { improvement of functioning. }\end{array}$ \\
\hline $\begin{array}{l}\text { Proposed } \\
\text { diagnosis on } \\
\text { review }^{c}\end{array}$ & Bipolar disorder & Progressive neurological disorder & Progressive neurological disorder & Progressive neurological disorder & Bipolar disorder & Bipolar disorder \\
\hline Loss of skills ${ }^{d}$ & & $+(\mathrm{M}, \mathrm{C})$ & & $+(M)$ & & \\
\hline $\begin{array}{l}\text { Other } \\
\text { information }\end{array}$ & & $\begin{array}{l}\text { Macrocephaly ( }>97^{\text {th }} \text { centile), with } \\
\text { normal height and weight (at age } \\
40 \mathrm{y} \text { ). }\end{array}$ & & & $\begin{array}{l}\text { Brain MRI at } 29 \text { y: hypoplasia of } \\
\text { the cerebellar vermis, enlarged } \\
\text { cisterna magna, and mild } \\
\text { enlargement of the lateral } \\
\text { ventricles }\end{array}$ & $\begin{array}{l}\text { Brain MRI at } 31 \text { y: hypoplasia of } \\
\text { the cerebellar vermis, enlarged } \\
\text { cisterna magna, and mild } \\
\text { enlargement of the lateral } \\
\text { ventricles }\end{array}$ \\
\hline
\end{tabular}


Table 1 PMS patients with neuropsychiatric decompensation reported in the literature (Continued)

\begin{tabular}{|c|c|c|c|c|c|c|}
\hline Case & 25 & 26 & 27 & 28 & 29 & 30 \\
\hline Reference & $\begin{array}{l}\text { Denayer et al. (2012) [11], Breckpot et al. } \\
\text { (2016) [33] }\end{array}$ & Denayer et al. (2012) [11] & Denayer et al. (2012) [11] & Denayer et al. (2012) [11] & Vucurovic et al. (2012) [10] & Smith et al. (2012) [34] \\
\hline Subject & Patient 4 (Denayer), Patient 2 (Breckpot) & Patient 5 & Patient 6 & Patient 7 & - & - \\
\hline $\begin{array}{l}\text { Age when } \\
\text { reported }\end{array}$ & $25 \mathrm{y}$ & $43 y$ & $46 y$ & 51 y & $18 \mathrm{y}$ & $23 y$ \\
\hline Sex & Female & Female & Male & Female & Male & Female \\
\hline $\begin{array}{l}\text { Genetic } \\
\text { abnormality }\end{array}$ & $\begin{array}{l}97 \mathrm{~kb} \text { terminal } 22 \mathrm{q} 13 \text { deletion including } \\
\text { SHANK3, de novo }\end{array}$ & $1.7 \mathrm{Mb}$ terminal $22 \mathrm{q} 13$ deletion & $1.2 \mathrm{Mb}$ terminal $22 \mathrm{q} 13$ deletion & 3.4 Mb terminal $22 \mathrm{q} 13$ deletion & $\begin{array}{l}\text { Translocation t(14,22) with } 3 \text { small } \\
\text { microdeletions of the SHANK3 region } \\
\text { and a } 748 \mathrm{~kb} \text { terminal } 14 \mathrm{q} 32.33 \\
\text { duplication. The } 3 \text { deletions occurred } \\
\text { de novo. }\end{array}$ & $\begin{array}{l}\text { 22q13.3 deletion syndrome (no } \\
\text { details) }\end{array}$ \\
\hline $\begin{array}{l}\text { Cognitive deficit, } \\
\text { language, and } \\
\text { behavioral } \\
\text { problems }\end{array}$ & Severe ID, single words, ASD & Severe ID, single words & Profound ID, no speech & Profound ID, no speech & $\begin{array}{l}\text { Severe ID, poor language } \\
\text { development, inattention, } \\
\text { hyperactive and impulsive } \\
\text { behavior, sleep disorder } \\
\text { associating successive } \\
\text { hypersomnia and insomnia } \\
\text { periods. No autistic features. }\end{array}$ & $\begin{array}{l}\text { Global developmental delay, } \\
\text { nonverbal }\end{array}$ \\
\hline $\begin{array}{l}\text { Age of onset of } \\
\text { deterioration }\end{array}$ & $19 y$ & $30 \mathrm{y}$ & $16 y$ & $\sim 22 \mathrm{y}$ & $16 y$ & $18 \mathrm{y}$ \\
\hline $\begin{array}{l}\text { Signs of } \\
\text { decompensation, } \\
\text { course of illness, } \\
\text { and treatment }\end{array}$ & $\begin{array}{l}\text { Extreme cycling of mood and psychomotor } \\
\text { activity, dissuptive behavior, self-injury, } \\
\text { echolalia and anxiety. The patient was } \\
\text { diagnosed with bipolar disorder (with rapid } \\
\text { cycling and psychotic features) at the age } \\
\text { of } 19 \text { y. Later, symptoms of catatonia } \\
\text { developed, in which the patient stopped } \\
\text { moving and talking, and required tube } \\
\text { feeding. } \\
\text { Initial treatment with antipsychotics and } \\
\text { benzodiazepines led to a poor response. } \\
\text { Higher doses led to increases in body } \\
\text { temperature and the fear of neuroleptic } \\
\text { malignant syndrome, and neuroleptics } \\
\text { were discontinued. Several days after } \\
\text { discontinuation, the patient was } \\
\text { hospitalized due to a sudden decrease in } \\
\text { blood pressure with decreased } \\
\text { consciousness that was thought to be } \\
\text { due to excess benzodiazepines, but may } \\
\text { have been a catatonic stupor, since it was } \\
\text { followed by other signs of catatonia. } \\
\text { Paroxetine was started. Afterwards, the } \\
\text { patient exhibited more pronounced } \\
\text { mood swings with fluctuating agitation, } \\
\text { anxiety, loss of language and social skills, } \\
\text { including no longer recognizing her } \\
\text { mother, she stopped eating } \\
\text { independently and lost continence. } \\
\text { Paroxetine was stopped after her } \\
\text { temperature rose and she became more } \\
\text { restless. Lithium, divalproes sodium, and } \\
\text { carbamazepine led to partial response but } \\
\text { continued symptoms. } \\
\text { After the diagnosis of catatonia was } \\
\text { established, the patient was treated } \\
\text { with lorazepam, and a few years later } \\
\text { with ECT. Psychiatric symptoms are } \\
\text { currently under control. }\end{array}$ & $\begin{array}{l}\text { Bipolar disorder with progressive } \\
\text { loss of skills }\end{array}$ & $\begin{array}{l}\text { Mood cycling with irritability, and } \\
\text { sleep disturbance. Bipolar disorder } \\
\text { was diagnosed at } 16 \text { y. At } 27 \text { y of } \\
\text { age, the patient was hospitalized } \\
\text { in the intensive care unit due to } \\
\text { neuroleptic malignant syndrome } \\
\text { during a manic episode treated } \\
\text { with high doses of haloperidol. } \\
\text { After this hospitalization, the } \\
\text { patient lost the ability to walk or } \\
\text { eat independently, requiring } \\
\text { extensive rehabilitation. } \\
\text { At } 40 \text { y, he was hospitalized for } \\
\text { septic shock due to aspiration } \\
\text { pneumonia. He subsequently } \\
\text { again lost skills of ambulation, } \\
\text { language, eating independently, } \\
\text { toileting, and dressing. } \\
\text { These skills have not returned and } \\
\text { the patient is currently spastic and } \\
\text { wheelchair-bound despite } \\
\text { ongoing treatment with } \\
\text { divalproex sodium. }\end{array}$ & $\begin{array}{l}\text { Diagnosed with bipolar disorder } \\
\text { at } 22 \mathrm{y} \text {. Experienced status } \\
\text { epilepticus at } 45 \text { y of age and } \\
\text { subsequently became totally } \\
\text { dependent and bedridden. }\end{array}$ & $\begin{array}{l}\text { At the age of } 10 \text { y, the patient had } \\
\text { an episode of psychomotor } \\
\text { agitation with insomnia lasting } 3 \\
\text { days. At around the age of } 16 y \text {, he } \\
\text { displayed depressive mood and } \\
\text { social isolation. Antidepressant } \\
\text { treatment was started and within } 2 \\
\text { months, he became increasingly } \\
\text { agitated with insomnia, impulsivity, } \\
\text { and aggression. Inpatient psychiatric } \\
\text { hospitalization was required, where } \\
\text { he was found to be euphoric, } \\
\text { disinhibited, with decreased need for } \\
\text { sleep, psychomotor agitation, } \\
\text { anorexia with weight loss, and poor } \\
\text { attention span with concentration } \\
\text { difficulties. His mood would also } \\
\text { rapidly shift to depression and he } \\
\text { was diagnosed with bipolar disorder. } \\
\text { He developed stereetyped behavior } \\
\text { with regression of expressive speech } \\
\text { and lost bladder control at the age } \\
\text { of } 17 \text {. Early-onset dementia was } \\
\text { hypothesized. } \\
\text { Antidepressant treatment } \\
\text { exacerbated psychomotor } \\
\text { agitation. Carbamazepine and } \\
\text { aripiprazole stabilized his mood } \\
\text { changes and improved attention } \\
\text { and concentration. Motor } \\
\text { hyperactivity persisted. }\end{array}$ & $\begin{array}{l}\text { New onset irritability, aggressive } \\
\text { behaviors, and periodic catatonia } \\
\text { (every } 6-8 \text { weeks) developed at } \\
\text { the age of } 18 \mathrm{y} \text {. } \\
\text { Treatment with lorazepam was } \\
\text { reportedly beneficial. ECT had } \\
\text { been tried in the past without } \\
\text { success. }\end{array}$ \\
\hline $\begin{array}{l}\text { Proposed } \\
\text { diagnosis on } \\
\text { review }{ }^{c}\end{array}$ & Bipolar disorder with catatonia & Bipolar disorder & $\begin{array}{l}\text { Bipolar disorder, likely brain insult } \\
\text { secondary to septic shock }\end{array}$ & $\begin{array}{l}\text { Bipolar disorder, brain insult } \\
\text { secondary to status epilepticus or } \\
\text { underlying cause of status } \\
\text { epilepticus }\end{array}$ & Bipolar disorder & Unspecified catatonia \\
\hline Loss of skills ${ }^{d}$ & $+(L, A)$ & + & $+(L, M, A)$ & $+(M, A)$ & $+(L, A)$ & \\
\hline $\begin{array}{l}\text { Other } \\
\text { information }\end{array}$ & $\begin{array}{l}\text { Brain MRl at } 9 \mathrm{y} \text { and } C T \text { at } 19 \mathrm{y} \text { were } \\
\text { normal }\end{array}$ & $\begin{array}{l}\text { Brain } \subset \text { at } 19,25 \text { and } 41 \text { y: } \\
\text { corticosubcortical atrophy }\end{array}$ & $\begin{array}{l}\text { Brain } \subset \text { at } 19 \text { and } 30 \mathrm{y} \text { : normal; at } \\
40 \mathrm{y} \text { : basal ganglia infarctions }\end{array}$ & $\begin{array}{l}\text { Brain } \subset T \text { at } 43 \text { y: mild } \\
\text { corticosubcortical atrophy }\end{array}$ & $\begin{array}{l}\text { Normal brain MRI at } 16 \mathrm{y} \text {. } \\
\text { Analysis of cerebrospinal fluid } \\
\text { revealed a slight decrease in } \\
\text { amyloid beta, low total tau and } \\
\text { normal phosphorylated tau } \\
\text { protein. }\end{array}$ & \\
\hline
\end{tabular}


Table 1 PMS patients with neuropsychiatric decompensation reported in the literature (Continued)

\begin{tabular}{|c|c|}
\hline 35 & 36 \\
\hline Guilherme et al. (2014) [37] & Serret et al. (2015) [38] \\
\hline Patient 5 & Case 1 \\
\hline $15 \mathrm{y}$ & $21 y$ \\
\hline Male & Male \\
\hline
\end{tabular}

\begin{tabular}{|c|c|c|c|c|}
\hline Case & 31 & 32 & 33 & 34 \\
\hline Reference & Verhoeven et al. (2013) [12] & $\begin{array}{l}\text { Messias et al. (2013) [35], McKelvey } \\
\text { et al. (2018) [36] }\end{array}$ & Soorya et al. (2013) [17] & Leblond et al. (2014) [7] \\
\hline Subject & - & - & SH25 & AUN_002 \\
\hline $\begin{array}{l}\text { Age when } \\
\text { reported }\end{array}$ & $70 y$ & 41 y & $45 y$ & NA \\
\hline Sex & Female & Female & Male & Male \\
\hline $\begin{array}{l}\text { Genetic } \\
\text { abnormality }\end{array}$ & $611 \mathrm{~kb}$ terminal $22 \mathrm{q} 13$ deletion & $\begin{array}{l}r(22) \text { with a terminal } \\
22 q 13.32 q 13.33 \text { deletion }\end{array}$ & $\begin{array}{l}4.4 \mathrm{Mb} \text { terminal } 22 \mathrm{q} 13 \text { deletion, } \\
\text { de novo }\end{array}$ & $\begin{array}{l}\text { SHANK3 frameshift mutation (NM_ } \\
\text { 033517.1:.4.4014_4015delAG, } \\
\text { p.Gly1339Glufs*5), not maternal }\end{array}$ \\
\hline $\begin{array}{l}\text { Cognitive deficit, } \\
\text { language, and } \\
\text { behavioral } \\
\text { problems }\end{array}$ & $\begin{array}{l}\text { Severe ID, severe language delay with } \\
\text { monosyllabic word sentences, and } \\
\text { behavioral problems }\end{array}$ & Moderate ID, verbal, friendly & ID, ASD, aggression & Severe ID, nonverbal, ASD \\
\hline $\begin{array}{l}\text { Age of onset of } \\
\text { deterioration }\end{array}$ & Twenties ${ }^{n}$ & $32 y$ & $17 y$ & NA \\
\hline $\begin{array}{l}\text { Signs of } \\
\text { decompensation, } \\
\text { course of illness, } \\
\text { and treatment }\end{array}$ & $\begin{array}{l}\text { Challenging, negativistic behaviors } \\
\text { intensified, over several years and } \\
\text { necessitated institutionalization at the } \\
\text { age of } 19 \text {. During her } 20 \text { s, speech } \\
\text { became mainly incomprehensible. } \\
\text { Mood cycling, disinhibited behaviors, } \\
\text { and sleep disturbances markedly } \\
\text { increased. During this period, the } \\
\text { patient underwent several surgical } \\
\text { corrections for painful cramping and } \\
\text { abnormal posturing of the hands } \\
\text { (neurolepticinduced tardive dystonia). } \\
\text { Over the following } 3 \text { decades, episodes } \\
\text { of psychomotor agitation and sleep } \\
\text { disturbances persisted. In addition, } \\
\text { there were recurrent gastro-intestinal } \\
\text { complaints for which no underlying } \\
\text { cause could be found. Over subsequent } \\
\text { years, her behavioral presentation } \\
\text { remained mainly unchanged, although } \\
\text { there were several periods during } \\
\text { which inactivity was more prominent. } \\
\text { At the age of } 64 \text { y, the patient } \\
\text { developed mania with anxiety and } \\
\text { agitated behavior and treatment was } \\
\text { initiated. Despite treatment, her } \\
\text { condition gradually deteriorated over a } \\
\text { period of } 5 \text { y. The diagnosis of bipolar } \\
\text { disorder was established. } \\
\text { Treatment was started with divalproex } \\
\text { sodium, and later replaced by } \\
\text { carbamazepine. One year later, lithium } \\
\text { was added. Maintenance treatment } \\
\text { included lithium carbonate (800 mg/d; } \\
\text { level = } 0.7 \mathrm{~mm} \text { mol/l) and carbamazepine } \\
\text { (1,000 mg/d; level = } 7.1 \mathrm{mg} / 1) \text {, as well } \\
\text { as pipamperone ( } 40 \mathrm{mg} \text { tid). Due to } \\
\text { ongoing symptoms, lithium was } \\
\text { gradually tapered off, and staff } \\
\text { members utilized behavioral strategies } \\
\text { with the patient, which resulted in } \\
\text { improvement of behavior and sleep. } \\
\text { Carbamazepine was then reduced to } \\
600 \mathrm{mg} / \mathrm{d} \text { with pipamperone ( } 40 \mathrm{mg} \\
\text { tid) as maintenance therapy. }\end{array}$ & $\begin{array}{l}\text { Mood and behavior were stable } \\
\text { until her first psychiatric } \\
\text { hospitalization at the age } 32 \text { y, } \\
\text { when she began having cyclic } \\
\text { episodes of mood dyssegulation } \\
\text { and loss of skills, including } \\
\text { bathing, dressing, and feeding. } \\
\text { The episodes lasted for periods of } \\
\text { weeks, during which she became } \\
\text { nonverbal, confused, detached, } \\
\text { and incontinent. She often stared } \\
\text { at her hands, at times shaking or } \\
\text { screaming, and refused to eat. } \\
\text { Symptoms responded poorly to } \\
\text { SSRI or benzodiazepine } \\
\text { monotherapy, but relatively } \\
\text { quickly to quetiapine (300 mg } \\
\text { twice daily), with significant } \\
\text { improvements in affect, speech, } \\
\text { and level of independence. } \\
\text { Psychotic symptoms resolved and } \\
\text { there was normalization of her } \\
\text { sleep/wake cycle. However, } \\
\text { cyclical episodes of depression } \\
\text { and catatonia persisted, eventually } \\
\text { requiring hospititlization. } \\
\text { After admission for prolonged } \\
\text { catatonia at age } 41, \text { a brain MRI } \\
\text { revealed bilateral acoustic } \\
\text { neuromas and multiple } \\
\text { intracranial meningiomas, } \\
\text { consistent with neurofibromatosis } \\
\text { type } 2 \text { (related to ing } 22 \text {. She } \\
\text { had no additional physical } \\
\text { findings of NF2. Neurosurgery was } \\
\text { not deemed necessary. After } \\
\text { multiple subsequent } \\
\text { pharmacological treatments failed, } \\
\text { she was treated with ECT with } \\
\text { significant improvement in mood. } \\
\text { The patient is currently stable on } \\
\text { lithium and citalopram. She has } \\
\text { stable mild sensorineural hearing } \\
\text { loss, no seizure activity and no } \\
\text { change in her tumors on annual } \\
\text { monitoring with MRI. }\end{array}$ & $\begin{array}{l}\text { Loss of language and toileting } \\
\text { skills after being placed in a } \\
\text { residential program. }\end{array}$ & $\begin{array}{l}\text { The patient began experiencing } \\
\text { generalized tonic-clonic seizures } \\
\text { at } 8 y \text {, which were resistant to } \\
\text { treatment. Regression was } \\
\text { reported late in life (no other } \\
\text { information available), in addition } \\
\text { to ataxia and dysmetria. }\end{array}$ \\
\hline
\end{tabular}

Male kb terminal deletion, de novo (NM_033517.1: 1.3605

(NM_033517.1: :.3605_- 3608 delCCCT, p.Ser1202Cysf* ${ }^{*} 81$ ) de novo

Development was unremarkable until the age of $2 y$, when he and social interaction Autism

Severe ID, ASD, limited language uses short sentences to make equests, echolalia, stereotypic particularly biking.

$15 y+13 y$

New onset aggression after he started having seizures at the a of $15 \mathrm{y}$. Seizures were controlled with carbamazepine; aggressive (a)

Cheridol and risperidone.

After moving from an autism day-care center to an autism un at $13 y$, the patient showed verbal, and daily living skills stopped his farvite a stivities and stopped his favorite activities and with increased impulsivity negativistic behavior and apat Sleep disturbance with insomnia appeared. At age $15 y$, the patient required hospitalization in a child and adolescent psychiatric unit The patient received different psychotropic medications that were partially effective but accompanied by multiple side effects Antipsychotics were able to control aggressive behaviors and insomnia, but induced catatonia and elevated muscle enzy reduced catatonia symptoms bontrol impulsivity and didnt control impulsivity, and increased psychomotor agitation
confusion, and insomnia. Mood stabilizers had no clinical efficacy and induced side effects, such as DRESS syndrome (Drug Reaction with Eosinophilia and Systemic Symptoms) with carbamazepine. Antidepressants were not effective. Among multiple drug associations, only the combination of aripiprazole and clonazepam showed partial efficacy, facilitating the improvement in dally living, language, and motor skils for about 12 mons butwh no impact on behavior. Methylphenidate was not effective shouting Lithium was intially an introduced in association with other psychotropic medications (eg. methylphenidate) and for a short period ( $<2$ months), without dear clinical effects. At age 19 , there was no significant improvement, and the diagnosis of bipolar disorder was suspected. Lithium (1500 mg/d) and melatoni (4 mg/d) led to symptom stabilization over 3 months. Agitation, aggressiveness and regained autonomy in eate life regained autonomy in everyday life,
and urinary and bowel incontinence stopped. He no longer showed opposition, participated in activitis with other patients, and began riding his bicycle again. As he no longer had sleep disturbances. melatonin was discontinued after 3 months. One year after the beginning of lithium therapy, the patient moved to an adult group home and had recovered his baseline level of functioning. At a follow-up of $2 y$, he remained stable mEq/).

\begin{tabular}{|c|c|}
\hline $\begin{array}{l}\text { Proposed } \\
\text { diagnosis on } \\
\text { review }^{c}\end{array}$ & Bipolar disorder with catatonia \\
\hline Loss of skills ${ }^{d}$ & $+(L)$ \\
\hline $\begin{array}{l}\text { Other } \\
\text { information }\end{array}$ & $\begin{array}{l}\text { Brain MRI at } 70 \mathrm{y} \text { : cortical atrophy, } \\
\text { particularly in the frontal region, and } \\
\text { subtle periventricular white matter } \\
\text { changes }\end{array}$ \\
\hline
\end{tabular}

Bipolar disorder with catatonia NF2

$+(L, A)$ subtle p
changes
Unspecified decompensation

$+(L, A)$

$+(\mathrm{M})$
Unspecified decompensation

Bipolar disorder with catatonia
$+(L, M, A)$

Normal head CT
Normal brain MRI and EEG 
Table 1 PMS patients with neuropsychiatric decompensation reported in the literature (Continued)

\begin{tabular}{|c|c|c|c|c|c|c|}
\hline Case & 37 & 38 & 39 & 40 & 41 & 42 \\
\hline Reference & Serret et al. (2015) [38] ' & Egger et al. (2016) [32] & Egger et al. (2016) [32] & Egger et al. (2016) [32] & Egger et al. (2016) [32] & Egger et al. (2016) [32] \\
\hline Subject & Case 2 & Patient 1 & Patient 2 & Patient 3 & Patient 4 & Patient 7 \\
\hline $\begin{array}{l}\text { Age when } \\
\text { reported }\end{array}$ & $17 y$ & $44 y$ & $22 y$ & $33 \mathrm{y}$ & $23 y$ & $21 \mathrm{y}$ \\
\hline Sex & Female & Male & Female & Female & Female & Female \\
\hline $\begin{array}{l}\text { Genetic } \\
\text { abnormality }\end{array}$ & $\begin{array}{l}\text { SHANK3 nonsense mutation (NM } \\
\text { 033517.1: } 2425 \mathrm{G}>\mathrm{T} \text {, p.Glu809*), de novo }\end{array}$ & $\begin{array}{l}63 \mathrm{~kb} 22 \mathrm{q} 13.33 \text { deletion including } \\
\text { SHANK3 }\end{array}$ & $\begin{array}{l}\text { Unbalanced translocation 11;22 } \\
\text { with derivative chromosome } 22, \\
11 \mathrm{q} 24.2 \mathrm{q} 25 \text { duplication of } 8.77 \mathrm{Mb} \\
\text { and terminal } 22 \mathrm{q} 13.33 \text { deletion of } \\
512 \mathrm{~kb}\end{array}$ & $1.98 \mathrm{Mb} 22 \mathrm{q} 13.32 \mathrm{q} 13.33$ deletion & $\begin{array}{l}\text { Unbalanced translocation 8;22 } \\
\text { with terminal 22q13.33 deletion, } \\
\text { de novo }\end{array}$ & $\begin{array}{l}88 \mathrm{~kb} 22 \mathrm{q} 13.33 \text { deletion } \\
\text { including SHANK3 }\end{array}$ \\
\hline $\begin{array}{l}\text { Cognitive deficit, } \\
\text { language, and } \\
\text { behavioral } \\
\text { problems }\end{array}$ & $\begin{array}{l}\text { Severe ID, ASD. She presented echolalia } \\
\text { and stereotypic language with words } \\
\text { and short sentences used in everyday } \\
\text { life and in context. She enjoyed sports, } \\
\text { especially rock climbing and } \\
\text { gymnastics. }\end{array}$ & $\begin{array}{l}\text { Profound ID, virtually absent } \\
\text { speech, single words only }\end{array}$ & $\begin{array}{l}\text { Mild to moderate ID, limited } \\
\text { speech and receptive language, } \\
\text { ritualistic//compulsive behaviors, } \\
\text { sleep disturbances. Attended } \\
\text { special education until the age of } \\
18 \mathrm{y} \text {. }\end{array}$ & $\begin{array}{l}\text { Mild to moderate ID, poor } \\
\text { articulation, simple sentences }\end{array}$ & Profound ID, absent speech & $\begin{array}{l}\text { Mild to moderate ID, elementary } \\
\text { sentences }\end{array}$ \\
\hline $\begin{array}{l}\text { Age of onset of } \\
\text { deterioration }\end{array}$ & $12 y$ & Late adolescence & Late adolescence & Late adolescence & Late adolescence & Late adolescence \\
\hline $\begin{array}{l}\text { Signs of } \\
\text { decompensation, } \\
\text { course of illness, } \\
\text { and treatment }\end{array}$ & 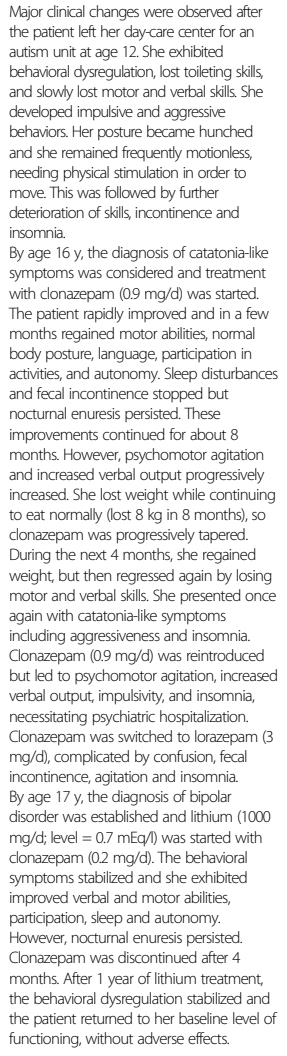 & $\begin{array}{l}\text { Diagnosed with bipolar disorder. } \\
\text { Treatment with pipamperone }(120 \\
\mathrm{mg} / \mathrm{d}) \text {, lamotrigine }(350 \mathrm{mg} / \mathrm{d}) \text {, } \\
\text { and levothyroxine }(125 \mathrm{\mu g} / \mathrm{d}) \\
\text { resulted in marked stabilization of } \\
\text { mood and behavior. }\end{array}$ & $\begin{array}{l}\text { Beginning in late adolescence, the } \\
\text { patient had recurrent mood changes } \\
\text { paralleled by an increase of pre- } \\
\text { existing autitistic behaviors. } \\
\text { Treatment with paroxetine } \\
\text { resulted in behavioral } \\
\text { deterioration with possible } \\
\text { hallucinations. On addition of } \\
\text { haloperidol, later replaced by } \\
\text { risperidone, the patient developed } \\
\text { a serotonin syndrome for which } \\
\text { she was hospitalized. } \\
\text { Discontinuation of all } \\
\text { psychotropic medication and } \\
\text { symptomatic treatment resulted in } \\
\text { a rapid remission of symptoms } \\
\text { and she was discharged to her } \\
\text { parent's home. A urinary tract } \\
\text { infection diagnosed during the } \\
\text { hospitalization was thought to } \\
\text { have contributed to her initial } \\
\text { deterioration of behavior. } \\
\text { Because her general functioning } \\
\text { did not reach baseline levels she } \\
\text { was referred for evaluation and } \\
\text { diagnosed with bipolar disorder. } \\
\text { Treatment with divalproex sodium } \\
\text { was started. After } 6 \text { months, a } \\
\text { dose of } 600 \text { mg/d (level = } 45 \mu g / \\
\text { ml) resulted in notable } \\
\text { stabilization of mood and } \\
\text { behavior, although baseline levels } \\
\text { of function were still not fully } \\
\text { attained and the addition of } \\
\text { quetiapine is being considered. }\end{array}$ & $\begin{array}{l}\text { Diagnosed with bipolar disorder. } \\
\text { Treatment with divalproex sodium } \\
(60 \mathrm{mg} / \mathrm{d}) \text { and quetiapine ( } 300 \\
\mathrm{mg} / \mathrm{d}) \text { resulted in marked } \\
\text { improvement of functioning. }\end{array}$ & Diagnosed with bipolar disorder & $\begin{array}{l}\text { Diagnosed with bipolar disorder. } \\
\text { Treatment with quetiapine ( } 1000 \\
\text { mg/d) resulted in marked } \\
\text { improvement of functioning. }\end{array}$ \\
\hline $\begin{array}{l}\text { Proposed } \\
\text { diagnosis on } \\
\text { review }^{c}\end{array}$ & Bipolar disorder with catatonia & Bipolar disorder & Bipolar disorder & Bipolar disorder & Bipolar disorder & Bipolar disorder \\
\hline Loss of skills ${ }^{d}$ & $+(L, M, A)$ & & & & & \\
\hline $\begin{array}{l}\text { Other } \\
\text { information }\end{array}$ & $\begin{array}{l}\text { Brain MRI, EEG and biological analyses } \\
\text { performed at the time of regression } \\
\text { were normal }\end{array}$ & & Normal brain MRl at age $22 \mathrm{y}$ & $\begin{array}{l}\text { Brain MRl: Hypoplasia of cerebellar } \\
\text { vermis and mild ventricular } \\
\text { enlargement }\end{array}$ & & \\
\hline
\end{tabular}


Table 1 PMS patients with neuropsychiatric decompensation reported in the literature (Continued)

\begin{tabular}{|c|c|c|c|c|c|c|}
\hline Case & 43 & 44 & 45 & 46 & 47 & 48 \\
\hline Reference & Breckpot et al. (2016) [33] & Fokstuen et al. (2016) [39] & Egger et al. (2017) [40] & Tabet et al. (2017) [41] & Tabet et al. (2017) [41] & Tabet et al. (2017) [41] \\
\hline Subject & Patient 1 & - & - & P3 & P9 & P11 \\
\hline $\begin{array}{l}\text { Age when } \\
\text { reported }\end{array}$ & $46 y$ & NA & $43 y$ & $16 y$ & $27 y$ & $37 y$ \\
\hline Sex & Female & NA & Male & Female $^{k}$ & Female & Female \\
\hline $\begin{array}{l}\text { Genetic } \\
\text { abnormality }\end{array}$ & $\begin{array}{l}97 \mathrm{~kb} 22 \mathrm{q} 13.33 \text { deletion including } \\
\text { SHANK3, de novo }\end{array}$ & $\begin{array}{l}\text { SHANK3 frameshift mutation (NM_ } \\
\text { 033517.1:..3637dupC, } \\
\text { p.His1213Profs*83) }\end{array}$ & $\begin{array}{l}\text { SHANK3 frameshift mutation (NM_ } \\
\text { 033517.1: } 1 \text { C.4523delC, } \\
\text { p.Thr1508Serfs*36) }\end{array}$ & $\begin{array}{l}\text { 22q13.33 deletion diagnosed by } \\
\text { FISH, de novo }\end{array}$ & $\begin{array}{l}\text { Unbalanced translocation } \mathrm{t}(2 ; 22) \\
\text { with } 5.07 \mathrm{Mb} \text { terminal } 22 \mathrm{q} 13 \\
\text { deletion, paternally derived }\end{array}$ & $\begin{array}{l}716 \mathrm{~kb} 22 \mathrm{q} 13 \text { terminal deletion, } \\
\text { de novo }\end{array}$ \\
\hline $\begin{array}{l}\text { Cognitive deficit, } \\
\text { language, and } \\
\text { behavioral } \\
\text { problems }\end{array}$ & Profound ID, autistic behavior & ID, mutism & $\begin{array}{l}\text { Severe ID, limited verbal skills, } \\
\text { ASD; destructive, self-injurious and } \\
\text { withdrawal behaviors during } \\
\text { childhood }\end{array}$ & $\begin{array}{l}\text { ID, non verbal (language } \\
\text { regression at } 18 \mathrm{~m} \text { ), autistic traits }\end{array}$ & $\begin{array}{l}\text { ID, non verbal, oppositional } \\
\text { defiant disorder }\end{array}$ & ID, speech delay, no autistic traits \\
\hline $\begin{array}{l}\text { Age of onset of } \\
\text { deterioration }\end{array}$ & $20 y^{\prime}$ & NA & $\sim 16 \mathrm{y}$ & $22 y$ & $17 y$ & NA \\
\hline $\begin{array}{l}\text { Signs of } \\
\text { decompensation, } \\
\text { course of illlness, } \\
\text { and treatment }\end{array}$ & $\begin{array}{l}\text { Diagnosed with unspecified psychosis } \\
\text { and catatonia. Inpatient in an adult } \\
\text { psychiatric unit. The first signs of severe } \\
\text { regression started around the age of } 20 \\
\text { y. } \\
\text { The first catatonic episode was treated } \\
\text { with lorazepam, the second with ECT, } \\
\text { with good response. Although ECT } \\
\text { resulted in remission of the catatonic } \\
\text { symptoms, the psychotic symptoms } \\
\text { remain, with inconsistent response to } \\
\text { psychopharmacological treatment. }\end{array}$ & Unspecified psychotic symptoms & 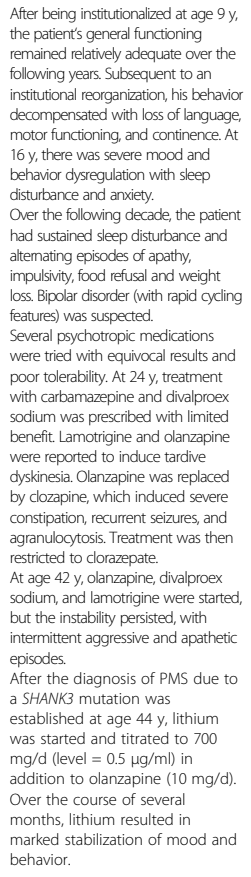 & $\begin{array}{l}\text { Severe hyperactivity and lack of } \\
\text { sleep with subsequent loss of } \\
\text { skills, particularly speech at the } \\
\text { age of } 22 \mathrm{y} \text {. }\end{array}$ & $\begin{array}{l}\text { Severe status epilepticus at age } \\
17 \text { y despite treatment with } \\
\text { antiepileptic medication, leading } \\
\text { to loss of cognitive skills, loss of } \\
\text { visual acuity, and loss of } \\
\text { locomotion. }\end{array}$ & $\begin{array}{l}\text { Diagnosed with bipolar disorder } \\
\text { and perceptual disturbances } \\
\text { (hallucinations). }\end{array}$ \\
\hline $\begin{array}{l}\text { Proposed } \\
\text { diagnosis on } \\
\text { review }^{c}\end{array}$ & $\begin{array}{l}\text { Unspecified psychotic disorder with } \\
\text { catatonia }\end{array}$ & Unspecified psychotic disorder & Bipolar disorder & Unspecified decompensation & Unspecified decompensation & Bipolar disorder \\
\hline Loss of skills ${ }^{d}$ & + & & $+(L, M, A)$ & $+(L)$ & $+(M, C)$ & \\
\hline $\begin{array}{l}\text { Other } \\
\text { information }\end{array}$ & $\begin{array}{l}\text { Cerebral and cerebellar atrophy; } \\
\text { postoperative seizure }\end{array}$ & & $\begin{array}{l}\text { Brain MRI at } 42 \text { y: discrete loss of } \\
\text { cerebral tissue predominantly in } \\
\text { the left hemisphere with enlarged } \\
\text { sulci. }\end{array}$ & & & \\
\hline
\end{tabular}


Table 1 PMS patients with neuropsychiatric decompensation reported in the literature (Continued)

\begin{tabular}{|c|c|c|c|c|c|c|}
\hline Case & 49 & 50 & 51 & 52 & 53 & 54 \\
\hline Reference & Tabet et al. (2017) [41] & Ballesteros et al. (2017) [42] & Lyons-Warren et al. (2017) [43] & De Rubeis et al. (2018) [4] & De Rubeis et al. (2018) [4] & De Rubeis et al. (2018) [4] \\
\hline Subject & P83 & - & - & s12 & B2 (MZ twin) & B3 (MZ twin) \\
\hline $\begin{array}{l}\text { Age when } \\
\text { reported }\end{array}$ & $23 y$ & $13 y$ & $16 y$ & $42 y$ & $14 \mathrm{y}$ & $14 y$ \\
\hline Sex & Male & Female & Female & Female & Female & Female \\
\hline $\begin{array}{l}\text { Genetic } \\
\text { abnormality }\end{array}$ & $619 \mathrm{~kb} 22 \mathrm{q} 13$ terminal deletion, de novo & 2.7 Mb 22q13 terminal deletion ' & $\begin{array}{l}\text { r(22) with } 1.036 \mathrm{Mb} \text { terminal } \\
22 \text { q13 deletion }\end{array}$ & $\begin{array}{l}\text { SHANK3 frameshift mutation (NM_ } \\
\text { 033517.1: c.4906_- } \\
\text { 4921dupTCCCCCGCCGTCGC, } \\
\text { p.Pro1641Leuf*58), de novo }\end{array}$ & $\begin{array}{l}\text { SHANK3 frameshift mutation } \\
\text { (NM_033517.1: c.4065_4066delTG, } \\
\text { p.Val1357Glyfs*4), de novo }\end{array}$ & $\begin{array}{l}\text { SHANK3 frameshift mutation } \\
\text { (NM_033517.1: c.4065_4066delTG, } \\
\text { p.Val1357Glyfs*4), de novo }\end{array}$ \\
\hline $\begin{array}{l}\text { Cognitive deficit, } \\
\text { language, and } \\
\text { behavioral } \\
\text { problems }\end{array}$ & $\begin{array}{l}\text { ID, speech delay, ASD, ADHD, } \\
\text { aggressive behavior }\end{array}$ & $I D, A S D$ & $\begin{array}{l}\text { ID, ASD; as a child, loss of } \\
\text { previously mastered vocabulary }\end{array}$ & $\begin{array}{l}\text { Profound ID, verbally fluent until } \\
\text { age } 12-13 y\end{array}$ & $\begin{array}{l}\text { Mild ID, speaks in full sentences } \\
\text { but developed word finding } \\
\text { difficulties. No ASD. Aggression. }\end{array}$ & $\begin{array}{l}\text { Mild ID. Spoke in full sentences } \\
\text { but regressed at } 9 \text { y to only say } \\
2-3 \text { words, regained some } \\
\text { vocabulary but fluctuating } \\
\text { language. No ASD. Aggression. }\end{array}$ \\
\hline $\begin{array}{l}\text { Age of onset of } \\
\text { deterioration }\end{array}$ & $20 y$ & $11 y$ & $16 y$ & $12-13 y$ & $13 y$ & $9-10 y$ \\
\hline $\begin{array}{l}\text { Signs of } \\
\text { decompensation, } \\
\text { course of illness, } \\
\text { and treatment }\end{array}$ & $\begin{array}{l}\text { Loss of cognitive skills with worsening } \\
\text { social communication impairment and } \\
\text { increased stereotyped behaviors at } 20 \mathrm{y} \text {. }\end{array}$ & $\begin{array}{l}\text { Behavioral dysregulation with } \\
\text { catatonic features and regression at } \\
\text { age } 11 \text { y that required psychiatric } \\
\text { hospitalization. } \\
\text { Different pharmacological } \\
\text { treatments, such as antipsychotics } \\
\text { and benzodiazepines, failed to } \\
\text { improve symptoms and led to } \\
\text { multiple adverse events. Lithium } \\
\text { therapy stabilized behavioral } \\
\text { symptoms and allowed the patient } \\
\text { to recover her baseline level of } \\
\text { functioning. After the first } \\
\text { menstruation there was cycling } \\
\text { through periods; risperidone was } \\
\text { suggested as adjunctive therapy but } \\
\text { the patient later stabilized with } \\
\text { lithium monotherapy. }\end{array}$ & $\begin{array}{l}\text { Symptoms began at age } 16 y \text { with a } \\
\text { personality change and subsequent } \\
\text { episodes of unprovoked anger. } \\
\text { The patient developed painless } \\
\text { growths on both arms. Brain MRI } \\
\text { revealed bilateral vestibular and spinal } \\
\text { schwannomas (which had not been } \\
\text { observed when MRI was performed at } \\
8 \text { y), consistent with a diagnosis of } \\
\text { neurofibromatosis type } 2 \text { (related to } \\
\text { ring 22). EEG revealed an epileptogenic } \\
\text { focus over the left temporal region. } \\
\text { The patient subsequently had } 1 \\
\text { episode of suspected seizure. She was } \\
\text { treated with bevacizumab with } \\
\text { significant improvement in her mood. }\end{array}$ & $\begin{array}{l}\text { Intermittent periods of behavioral } \\
\text { dysregulation with loss of } \\
\text { cognitive, motor and language } \\
\text { skills. Sometimes preceded by viral } \\
\text { infection. } \\
\text { Cognitive ability declined from } \\
\text { borderline intellectual functioning } \\
\text { before puberty to profound ID at } \\
\text { age } 42 \text {. The patient was verbally } \\
\text { fluent but became non-verbal. } \\
\text { She was walking independently at } \\
20 \text { months but currently is unable } \\
\text { to walk more than several steps } \\
\text { without support. Psychotic } \\
\text { symptoms were reported and } \\
\text { characterized by auditory and } \\
\text { visual hallucinations. She had } \\
\text { episodic periods of mania and } \\
\text { depression, insomnia, decreased } \\
\text { appetite and weight loss, } \\
\text { unsteady gait, and catatonic } \\
\text { posturing. }\end{array}$ & "Manic like" behavior & "Manic like" behavior \\
\hline $\begin{array}{l}\text { Proposed } \\
\text { diagnosis on } \\
\text { review }^{c}\end{array}$ & Unspecified decompensation & Bipolar disorder with catatonia & Unspecified decompensation, NF2 & Bipolar disorder with catatonia & Unspecified mood disorder & Unspecified mood disorder \\
\hline Loss of skills ${ }^{d}$ & $+(L, C)$ & + & & $+(L, M, C)$ & & \\
\hline $\begin{array}{l}\text { Other } \\
\text { information }\end{array}$ & & & & $\begin{array}{l}\text { Normal brain MRI at } 14 \mathrm{y} \text { and } 18 \\
\text { y. Macrocephaly (OFC } 57 \mathrm{~cm}, 99^{\text {th }} \\
\text { centile), with normal height and } \\
\text { weight (at age } 42 \mathrm{y} \text { ). }\end{array}$ & $\begin{array}{l}\text { Brain MRI at } 14 \text { y: mild cerebellar } \\
\text { tonsillar ectopia. Atypical absence } \\
\text { seizures, onset at } 14 \mathrm{y} \text {. Episode of } \\
\text { idiopathic intracranial } \\
\text { hypertension at } 12 \mathrm{y} \text {. Normal } \\
\text { OFC ( } 30^{\text {th }} \text { centile) at } 14 \mathrm{y} \text {. }\end{array}$ & $\begin{array}{l}\text { Normal brain MRI at } 14 \mathrm{y} \text {. } \\
\text { Atypical absence and tonic } \\
\text { seizures, onset at } 7 \mathrm{y} \text {. } \\
\text { Macrocephaly (OFC } 57 \mathrm{~cm}, 98^{\text {th }} \\
\text { centile) at } 14 \mathrm{y} \text {. }\end{array}$ \\
\hline
\end{tabular}


Table 1 PMS patients with neuropsychiatric decompensation reported in the literature (Continued)

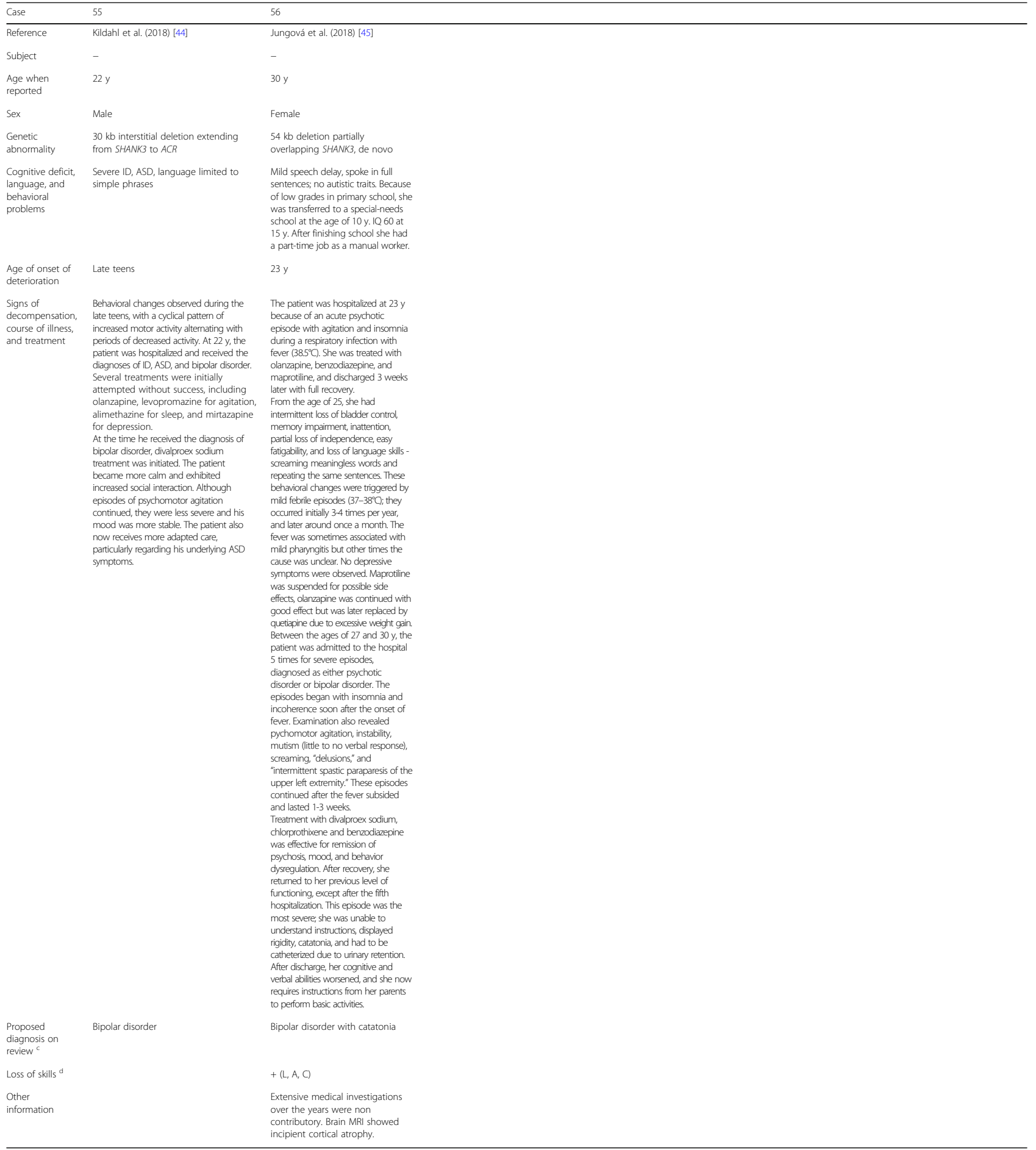

$\overline{A D H D}$ attention deficit hyperactivity disorder, $A S D$ autism spectrum disorder, $C T$ computed tomography, ECT electroconvulsive therapy, EEG electroencephalography, ID intellectual disability, $k b$ kilobase, $M b$ megabase, $M Z$ monozygotic, MRI magnetic resonance imaging, NA not available, NF2 neurofibromatosis type 2, OFC occipito-frontal circumference, PMS Phelan-McDermid syndrome, $r(22)$ ring chromosome 22, SSRI selective serotonin reuptake inhibitor, tid 3 times a day, $y$ years

apatient initially described by Richards et al. [46]

Patient initially reported by Kondo et al. [47] (Case 5)

'The diagnosis reported in the publication is mentioned above, in 'Signs of decompensation, course of illness, and treatment', when available.

Loss of skils: $L$ languge, $M$.

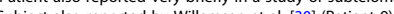

SSubject also reported by Willemsen et al. [30] (Patient 9 )

"Neuropsychiatric decompensation was reported to have occurred during the "second decade" in the original article; when contacted, the authors stated that it occurred during her twenties.

'Patient also reported by Leblond et al. [7] (AUN-003) and Daville et al. [49] (Patient 1)

Information provided by author

'Patient listed as male in Table S2 but referred to as 'her/she' in the clinical description in the supplement

'Patient was mistakenly reported to have a mutation in SHANK3; she has a 22q13 terminal deletion 


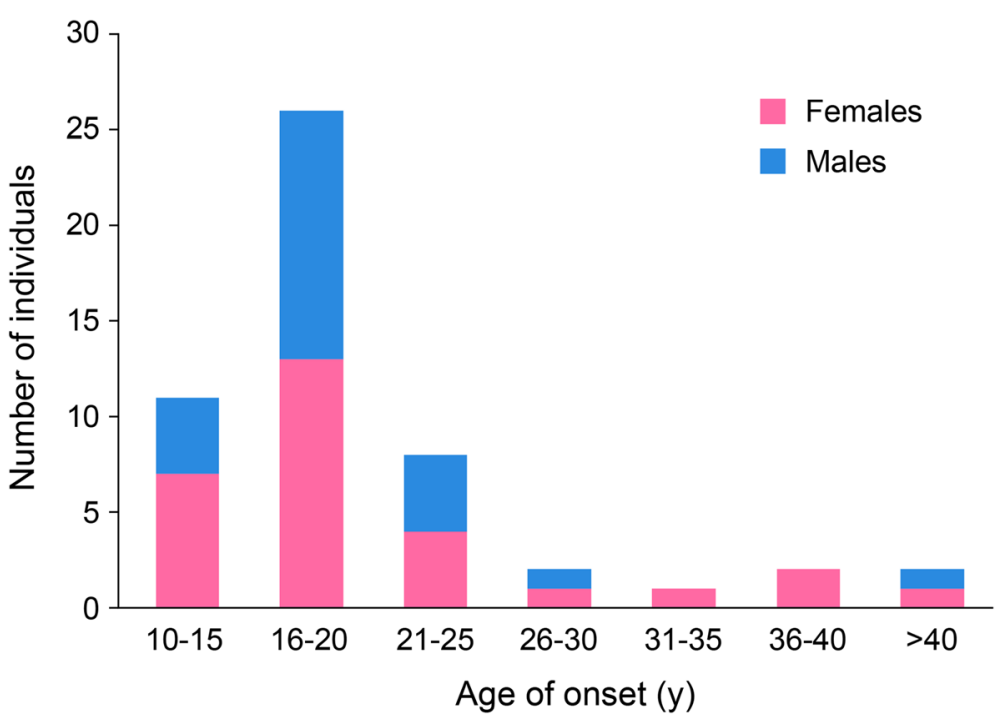

Fig. 1 Age of onset of regression or emergent psychiatric phenotypes. For each patient report where the onset of regression or the emergence of psychiatric phenotypes was clearly documented, we noted the age and summed the number of individuals in each bin. We omitted all cases without such information. Cases with onset in "late adolescence" or "late teens" were included in the 16-20 years bin (see Table 1). For those cases with a 2-year window of onset (i.e., 9-10 and 12-13), we used the later time point. Females and males were counted together but identified by differing colors

SHANK3 point mutations. In total, there were 42 individuals with deletions (23 simple deletions, 15 ring chromosome 22, 4 unbalanced translocations), and 14 with pathogenic or likely pathogenic sequence variants in SHANK3 (9 frameshift, 4 nonsense, and 1 missense variant).

Some reports have limited descriptions of the subjects, while others present a complete clinical evaluation. All individuals had ID, which was generally severe (20 out of 40); 8 had profound ID, 5 mild to moderate ID, 5 mild ID, and 2 had borderline IQ (no information about the level of ID was available for 16 individuals). Although language impairment was prominent, several individuals were reported to speak in full sentences at baseline. The mean age of onset of neuropsychiatric decompensation was 20 years (SD 8.4); the youngest patient showed changes at 9-10 years of age (P54) and the oldest at 51 years (P11). In $71 \%$ of the patients, the onset of neuropsychiatric symptoms occurred between the ages of 9 and 20, with a peak of onset at 16-20 years (Fig. 1). Although samples were small, there was no evidence of a sex difference in the age of onset (Fig. 1).

Thirty-one individuals exhibited significant loss of skills (17 females, 14 males) with a mean age at onset of 21 years. Thirty individuals had bipolar disorder (17 females, 13 males; mean age at onset 20 years); catatonia was reported in 16 (13 females, 3 males; mean age at onset 22 years), and psychosis in 7 (3 females, 3 males, 1 unknown gender; mean age at onset 17 years). Three patients had an unspecified mood disorder ( 2 females, 1 male; mean age at onset 11 years). At least four individuals had a progressive neurological disorder (2 females, 2 males), with juvenile onset in one (12 years) and adult onset in three (mean age 41 years). In addition, there were eight patients with unspecified decompensation and one with a likely neurological disorder, not included in the previous categories ( 3 females, 6 males; mean age at onset 18 years).

\section{Loss of skills}

Significant loss of skills was reported in 31 of 56 (55\%) individuals. Loss of skills is often referred to as "regression" in the literature reviewed but the details provided in most of the case reports do not clarify whether individuals clearly and consistently acquired skills for a prolonged period of time and then lost these skills, either permanently or for an extended period. In general, neuropsychiatric disorders such as bipolar disorder, catatonia, and psychosis may emerge with a loss of skills but most of the available reports do not clarify whether symptoms persisted beyond the acute psychiatric episodes. Loss of skills occurred in a variety of areas, most commonly affecting language (16 of 26 with information, 62\%) (for specific patient and types of loss of skills see Table 1), motor skills (16 of 27, 59\%), and activities of daily living, including toileting skills (16 of 26, 62\%). Cognition was also reportedly affected in many cases (8 of 26, 31\%). Motor skill loss was dramatic in several cases, leading individuals to be unable to walk in two cases (P20, P47), wheelchair 
bound in three cases (P12, P22, P27), or bedridden in one case (P28).

\section{Bipolar disorder}

Among the cases we reviewed, 30 of 56 (54\%) most likely met criteria for bipolar disorder. As with all psychiatric disorders, reliable diagnosis is challenging in intellectually disabled and minimally verbal individuals. Relying on the descriptions provided in the literature, however, several themes were common among individuals with PMS, consistent with the diagnosis of bipolar disorder. Among them, irritability, mood cycling or mood dysregulation was described in most $(n=20)$. Sleep was also highly disturbed in many $(n=16)$, with decreased need for sleep, insomnia, and sleep maintenance problems. Distractibility or short attention span was noted in at least four patients. Some patients were described as screaming $(n=3)$ or hyperactive during periods $(n=3)$. Loss of skills was also commonly associated, with $50 \%$ (15 of 30) of those with bipolar symptoms also having loss of function (Table 1), such as loss of language $(n=11)$, motor skills $(n=9)$, bathing and dressing skills $(n=1)$, weight loss/feeding issues $(n=9)$, cognition $(n=2)$, and continence $(n=6)$. Rapid cycling was noted in five individuals. Seven patients had symptoms where the severity reached the need for hospitalization. Fever or infection (P39, P52, P56) and first menses (P50) were potential antecedents.

A broad range of medications typically used for bipolar disorder were administered in most cases, but met with inconsistent success in PMS. Antipsychotics were most commonly prescribed, such as thioridazine, chlorpromazine, perphenazine, haloperidol, chlorprothixene, pipamperone, risperidone, olanzapine, aripiprazole, and quetiapine, either alone or in combination with anticonvulsants and/or benzodiazepines. No clear themes of effectiveness are evident based on our review, and if anything, antipsychotics were generally ineffective and often poorly tolerated. In one notable case (P19), different therapeutic responses were observed between lowand high-dose risperidone; high dose (6 $\mathrm{mg}$ daily) resulted in poor response and increased behavioral symptoms, while low dose ( $1 \mathrm{mg}$ daily) improved mood and behavior. In several cases, the combination of an antipsychotic and anticonvulsant, such as quetiapine with divalproex sodium (P23, P24, P40, P42), aripiprazole and carbamazepine (P29), pipamperone with carbamazepine (P31), or pipamperone and lamotrigine (P38), led to stabilization. Anticonvulsants such as divalproex sodium, lamotrigine, or carbamazepine were associated with at least partial success, as was lithium in several cases (P25, P32, P36, P37, P45). Overall, antidepressants were poorly tolerated and ineffective.

\section{Catatonia}

Sixteen of 56 cases reviewed (29\%) were reported to have symptoms of catatonia, most commonly in the context of bipolar disorder (12 of 16, 75\%). Several patients appeared to have acute triggers for their symptoms, including moving residences (P36, P37), or infection (P52, P56). Symptoms were highly variable but several patterns are noteworthy. Motor symptoms appeared to be common, with posturing and stereotypy, such as limb flexion, hunched posture, truncal instability, bradykinesia, upper extremity resting tremor, and stereotypic movements $(n=8)$. Some reports refer to "mild spastic paraparesis" (P2) or "intermittent spastic paraparesis of the upper left extremity" (P56) in patients with catatonia, which could be posturing or rigidity-characteristic motor signs of catatonia - and not true spasticity, particularly since spastic paraparesis would not describe signs in the upper extremities. Negativistic behaviors, stupor, and mutism were also thematic, with patients who stopped talking, moving, engaging in previously preferred activities, or refusing to eat, refusing to respond, and appearing apathetic $(n=7)$. Many patients were also described as exhibiting agitation $(n=6)$.

Regarding treatment of catatonia, benzodiazepines were used in some PMS cases with benefit (P30, P37, P56) but not in others (P50). Of note, electroconvulsive therapy (ECT) was typically effective when administered (P25, P32, P43). Antipsychotics were generally ineffective and poorly tolerated (P2, P25, P36), even inducing catatonia in at least one case (P36). It also appears that antidepressants and other serotonergic medications were associated with poor response and/or increased agitation in at least two cases (P32, P36). In many cases, lithium was used to treat the underlying bipolar disorder, often with success (P25, P31, P32, P36, P37, P50). Other antiepileptic medications were commonly used, either in combination, or alone, and often with benefit. Among them, divalproex sodium appears to be the most commonly used and with the most consistent beneficial effects (P25, P31, P56).

\section{Psychosis}

Seven of 56 patients (12.5\%) were either diagnosed with schizophrenia (P16, P17), schizoaffective disorder (P15, P18), or unspecified psychosis (P43), or deemed to likely have a psychotic disorder upon our review (P6, P44). One of these cases (P6) first presented with psychosis (paranoid delusions and hallucinations) at 17 years old and at 38 years old was discovered to have neurofibromatosis type 2 due to ring chromosome 22. Symptoms in the cases were otherwise poorly described beyond using the term psychosis or providing the diagnosis without accompanying details. At least one case with psychosis (P43) had catatonia and responded to 
lorazepam after one episode and to ECT after another. Insufficient data was provided to otherwise review or draw any conclusions about treatment themes.

\section{Neurologic signs and progressive deterioration}

Several individuals were reported with signs of what appears to be neurologic deterioration, such as development of parkinsonian signs, including resting tremor, bradykinesia, or mask facies, sometimes coupled with dysarthria, dysphagia, rigidity, or gait changes (P2, P3, $\mathrm{P} 6$, all with ring chromosome 22); unspecified tremor (P1, P21); gait changes $(n=12)$, including truncal or gait instability (P2, P3, P7, P52), ataxia (P34), paraparesis (P6, P20, P22, P27), or inability to walk (P12, P20, P22, P27, $\mathrm{P} 28, \mathrm{P} 47)$; and swallowing difficulties (P14, P22). Some of the gait changes may be attributable to catatonia, which was mentioned in the original publication or considered to be a likely diagnosis on review (P2, P3, P7, $\mathrm{P} 52)$, whereas in other cases they are likely a sign of a progressive neurological disorder (P6, P20, P22, P34), or related to an acute brain insult due to septic shock or status epilepticus (P27, P28, P47). In one individual (P10), the cognitive and physical deterioration accompanied by seizures and sensorimotor polyneuropathy with onset at 12 years of age were secondary to juvenile onset metachromatic leukodystrophy.

\section{Discussion}

In spite of the fact that fewer adolescent and adult patients with PMS are reported in the current literature compared to children, we identified 56 cases of PMS with neuropsychiatric decompensation, including 30 with loss of language, motor, or cognitive skills. While there are certainly ascertainment issues with this sample, these results suggest that neuropsychiatric decompensation and loss of skills in adolescence or adulthood could well be common in PMS and a part of the psychopathological phenotype of the disorder. It is important to note that neuropsychiatric decompensations occurred across a broad age range (9-51 years), but most commonly occurred between 16 and 20 years of age (Fig. 1). This observation is helpful to alert clinicians to this period of potentially increased risk, although it does not altogether allay concerns about later neuropsychiatric changes. The assessment and diagnosis of neuropsychiatric disorders in PMS is complicated by premorbid cognitive deficits, social communication impairment, and often restricted and repetitive behaviors. The Diagnostic and Statistical Manual for Mental Disorders, 5th edition [50] does not include modifications for patients with intellectual disability and limited language. Instead, the Diagnostic Manual - Intellectual Disability, Second Edition (DMID-2) [51] can be used for diagnosis and includes caregiver observations of behavior in addition to reducing the number of symptoms required for some diagnoses in order to remove criteria that require patients to describe their experiences.

\section{Loss of skills}

Loss of skills can be defined in many ways and the word "regression" is interpreted to mean different things in different contexts. Typically, loss of skills is thought of as a prolonged loss of skills previously acquired and the term is consistently used in conjunction with a clear history of specific skills lost for a prolonged period. The amount of time defined as "prolonged" can vary, but typically a minimum of 3 months is required. Because skill loss can also occur in the context of neuropsychiatric disorders, it is critical to assess whether the loss is confined to the acute psychiatric episode or extends beyond when psychiatric symptoms return to baseline. Loss of skills and neuropsychiatric symptoms may also be more easily detected in higher functioning patients and therefore appears to be overrepresented among cases with smaller deletions or SHANK3 mutations (see below). However, the extent of clinical information available in the literature to date makes it difficult to fully assess the nature of skill loss and whether losses would meet typical criteria for regression. Questions about the phenomenology of loss of skills and regression in childhood reported in PMS [4, 17-20] as compared to changes that occur in adolescence or adulthood remain. Finally, it is important to consider whether progressive increased severity of symptoms, with a decline in adaptive functioning, may implicate a neurodegenerative process or early onset of dementia.

Ten patients were reported with "atrophy" on brain imaging, most commonly involving the cerebral cortex, and in a few cases, subcortical structures (Table 2). These patients ranged in age from 19-70, and most were under age 45 when they had imaging. One was age 70, so cortical atrophy might be expected. Without serial scans showing a progressive change, it is hard to know if this is a meaningful change related to regression, and whether it is true atrophy or just a congenital small brain, perhaps due to PMS or other genetic changes in deletion carriers. If true progressive atrophy, this would raise the question of a secondary gene effect, particularly in deletion carriers, due to unmasking of a recessive variant in a gene in the deleted interval. Indeed, one of the individuals with diffuse cerebral and cerebellar atrophy at age 12 years had juvenile onset metachromatic leukodystrophy, also known as arylsulfatase A (ARSA) deficiency. It is important to note that white matter changes are not always obvious in adult and older juvenile cases of metachromatic leukodystrophy and these can present with psychiatric symptoms followed by gait changes such as spasticity or ataxia [52]. Thus, adolescents or adults with decompensation and 22q13.33 
Table 2 PMS patients with neuropsychiatric decompensation and atrophy on brain imaging

\begin{tabular}{|c|c|c|c|c|}
\hline Case & Age at imaging & $\begin{array}{l}\text { Imaging } \\
\text { technique }\end{array}$ & Findings & Proposed diagnosis on review \\
\hline 2 & 27 y & CT & Diffuse mild cortical atrophy and hydrocephalus ex vacuo & Bipolar disorder with catatonia \\
\hline 10 & 12 y & MRI & Diffuse cerebral and cerebellar atrophy & Metachromatic leukodystrophy \\
\hline 11 & 52 y & $\mathrm{CT}$ & Cerebral atrophy, with multiple intracranial meningiomas & $\begin{array}{l}\text { Bipolar disorder with catatonia, } \\
\text { neurofibromatosis type } 2\end{array}$ \\
\hline 22 & $45 \mathrm{y}$ & MRI & $\begin{array}{l}\text { Normal, except for mild enlargement of the cisterna magna and } \\
\text { central atrophy }\end{array}$ & Progressive neurological disorder \\
\hline 26 & 19,25 , and $41 \mathrm{y}$ & $\mathrm{CT}$ & Corticosubcortical atrophy & Bipolar disorder \\
\hline 28 & 43 y & $\mathrm{CT}$ & Mild corticosubcortical atrophy & Bipolar disorder \\
\hline 31 & $70 y$ & MRI & $\begin{array}{l}\text { Cortical atrophy, particularly in the frontal region, and subtle } \\
\text { periventricular white matter changes }\end{array}$ & Bipolar disorder with catatonia \\
\hline 43 & $\begin{array}{l}\text { NA (between } 20 \\
\text { and } 46 \mathrm{y} \text { ) }\end{array}$ & NA & Cerebral and cerebellar atrophy & $\begin{array}{l}\text { Unspecified psychotic disorder with } \\
\text { catatonia }\end{array}$ \\
\hline 45 & $42 y$ & MRI & $\begin{array}{l}\text { Discrete loss of cerebral tissue predominantly in the left } \\
\text { hemisphere with enlarged sulci }\end{array}$ & Bipolar disorder \\
\hline 56 & $\begin{array}{l}\text { NA (between } 23 \\
\text { and } 30 \mathrm{y} \text { ) }\end{array}$ & MRI & Incipient cortical atrophy & Bipolar disorder with catatonia \\
\hline
\end{tabular}

CT computed tomography, MRI magnetic resonance imaging, NA not available, $y$ years

deletions including ARSA should be screened for this disorder (ARSA enzyme deficiency in blood leukocytes or urinary excretion of sulfatides, confirmed by biallelic pathogenic variants in ARSA on genetic testing).

\section{Bipolar disorder}

According to the DSM-5, the diagnosis of bipolar disorder requires at least one lifetime manic episode defined as a distinct period of "persistently elevated, expansive, or irritable mood and persistently increased goal directed activity or energy, lasting at least 1 week and present most of the day, nearly every day" [50]. During this period, at least four symptoms are required, most of which may require some adaptation for persons with ID: (1) inflated self-esteem or grandiosity (may include exaggerated claims of accomplishment or skills for developmentally delayed people); (2) decreased need for sleep (or pronounced sleep disturbance); (3) more talkative than usual (or increased screaming, vocalizations, or other noise-making if minimally verbal); (4) flight of ideas or racing thoughts (when developmentally relevant); (5) distractibility (may manifest as diminished selfcare skills in persons with ID or loss of productivity at work or day program); (6) increased goal-directed activity (people with ID may appear "sped up" or unable to sit still); (7) excessive involvement in pleasurable activities (in people with ID this may manifest as excessive masturbation, exposing self in public, or inappropriate sexual touching). If four or more distinct episodes of mania (or depression or hypomania) occur in the context of bipolar disorder during the past year, the course specifier of "rapid cycling" is applied [50].
Half the cases we reviewed met the criteria for bipolar disorder, including 12 with catatonia. Despite the challenges in reliably making the diagnosis in individuals with PMS who are intellectually disabled and often minimally verbal, the clinical themes that emerged were convincing. Irritability, mania, mood cycling, or mood dysregulation was commonly described, in addition to sleep disturbance, distractibility, and psychomotor hyperactivity. Many patients required hospitalization and loss of skills was commonly reported, most often in the language domain. Triggers were noted in some patients, including infection or menses; while insufficient evidence exists to establish any causal connections, the phenomenon may be useful for monitoring and possibly prevention in some cases. As is typical in PMS, treatment was challenging but antipsychotics were minimally effective and generally poorly tolerated. In some cases, the combination of a second generation antipsychotic (e.g., quetiapine, aripiprazole) with an anticonvulsant (e.g., divalproex sodium, carbamazepine, lamotrigine) was associated with good responses. Lithium should likewise be considered in cases of PMS with bipolar disorder. It would seem that in cases with an underlying mood cycling disorder, antidepressants are rarely associated with positive effects, and are often poorly tolerated. In all, these treatment strategies are generally aligned with guidelines for the management of bipolar disorder in the general population [53]. While our manuscript was under review, a case series was published documenting the longitudinal course and treatment of 24 individuals with PMS with accompanying neuropsychiatric symptoms [54]. Atypical bipolar disorder was diagnosed in 18 patients. In 
agreement with previous findings, treatment with a mood stabilizer (divalproex sodium or lithium), sometimes in conjunction with an atypical antipsychotic (olanzapine or quetiapine), was reported to result in gradual stabilization of mood and behavior in most individuals.

\section{Catatonia}

The DSM-5 defines catatonia as a specifier diagnosed in the context of another medical condition or associated mental disorder (e.g., bipolar disorder). The clinical picture is characterized by at least three of the following symptoms: (1) stupor (i.e., no psychomotor activity; not actively relating to environment); (2) catalepsy (i.e., passive induction of a posture held against gravity); (3) wavy flexibility (i.e., slight, even resistance to positioning by examiner); (4) mutism (i.e., no, or very little, verbal response); (5) negativism (i.e., opposition or no response to instructions or external stimuli); (6) posturing (i.e., spontaneous and active maintenance of a posture against gravity); (7) mannerisms (i.e., odd, circumstantial caricature of normal actions); (8) stereotypy (i.e., repetitive, abnormally frequent, non-goal-directed movements); (9) agitation, not influenced by external stimuli; (10) grimacing; (11) echolalia (i.e., mimicking another's speech); and (12) echopraxia (i.e., mimicking another's movements) [50]. Of course, as the DM-ID2 notes, mutism, mannerisms, stereotypies, and grimacing can be features of ID, and echolalia can be a feature of ASD, so the history and time of onset of these symptoms is critical to delineate [51]. It is clear that catatonia often goes undiagnosed in individuals with intellectual and developmental disabilities [55] and yet appears to be a common feature of the neuropsychiatric presentation of PMS based on our review. The preponderance of females affected by catatonia was also notable (13 females versus 3 males), especially given the roughly equal sex ratio in PMS [56] and the fact that most youth diagnosed with catatonia are males [57, 58]. Thus, this observation needs to be confirmed in larger samples of individuals with PMS with a confirmed diagnosis of catatonia.

Benzodiazepines are typically the first line treatment for catatonia and were used in some PMS cases with benefit, albeit inconsistently. However, dosing information was not always available in the literature. Often response requires high doses (e.g., lorazepam $8 \mathrm{mg}$ three times daily), with the caveat that dosing should always begin low (e.g., lorazepam $0.5-1 \mathrm{mg}$ three times daily) and be titrated slowly with careful monitoring of vital signs. If benzodiazepines fail or provide only a partial response, ECT is considered the gold standard of care for catatonia [59] and was effective in most cases. Lithium should be considered in cases with bipolar disorder and catatonia, as response rates appeared relatively robust according to this review. Although commonly used, antipsychotics should be administered with caution in the patients given their limited benefit, pronounced side effects, and the potential risk of inducing catatonia. Despite this, some cases appeared to respond to the combination of second-generation antipsychotics (e.g., quetiapine) and anticonvulsants (e.g., divalproex sodium) or lithium. Antidepressants, especially in patients with mood cycling, show poor response and increased risk for symptom exacerbation.

\section{Psychosis}

The diagnosis of schizophrenia requires that two or more symptoms during a significant proportion of at least one month (or less if successfully treated) be present to meet DSM-5 criteria, including (1) delusions, (2) hallucinations, (3) disorganized speech, (4) disorganized or catatonic behavior, and (5) negative symptoms. In addition, individuals must have at least one of the first three symptoms (delusions, hallucinations, disorganized speech). Level of functioning or self-care must be markedly below baseline functioning and there must be continuous signs of the disturbance for at least 6 months. If depressive or manic episodes occur concurrently, a diagnosis of schizoaffective disorder is more appropriate [50]. Although the DM-ID-2 does not delineate any significant adaptations for individuals with ID, criterion $\mathrm{F}$ of the DSM-5 does specify if there is a history of ASD or "a communication disorder of childhood-onset," the diagnosis of schizophrenia requires the presence of delusions of hallucinations for at least 1 month (or less if successfully treated).

A minority of cases reviewed presented with psychotic symptoms and most reports provided too few details to reliably make the diagnosis of a primary psychotic disorder. Four cases were diagnosed explicitly with schizophrenia or schizoaffective disorder [28], all of whom had ID and were between the ages of 11 and 21 years-old. While it is likely that they experienced a psychiatric decompensation consistent with what is described in the other cases reviewed, confidence in the diagnosis of schizophrenia or schizoaffective disorder is undermined by the paucity of detail provided and the inherent challenges in making these diagnoses in intellectually disabled and developmentally delayed populations. No conclusions could be garnered regarding potential treatment of psychosis.

\section{Neurologic signs and progressive deterioration}

Neurological signs observed in patients are diffuse and fall into categories of parkinsonism, tremor, gait changes due to ataxia, spasticity and others, and dysphagia as well as other descriptive changes. Some of these could be drug related (parkinsonian symptoms induced by antipsychotics, and tremor induced by lithium or 
divalproex sodium), related to neurological decompensation in a compromised brain with aging or illness, or a part of catatonia/psychiatric status. Others do appear to follow a persistent progressive neurodegenerative course (P20, P21, P22), which suggests a co-morbid neurological disorder. One patient (P10) is known to have such a disorder (metachromatic leukodystrophy) and others could have either this or another recessive disorder unmasked by the 22q13 deletion or a coincidental unrelated disorder. Onset of neurological conditions such as adult-onset metachromatic leukodystrophy in an individual with PMS could be particularly difficult to distinguish early in the disease course as later onset metachromatic leukodystrophy and other neurological diseases often present with psychiatric symptoms, and these symptoms may be difficult to interpret in a setting of ID and/or ASD.

\section{Role of SHANK3}

Neurobehavioral decompensation, including bipolar disorder, catatonia, and loss of skills, was observed in cases with PMS regardless of the underlying genetic defect, consistent with a role of SHANK3 in the psychopathological phenotype emerging as patients age. In fact, severe neuropsychiatric decompensation has been reported in 14 individuals with SHANK3 point mutations $[2,4,7,28,38-40]$. These results indicate that SHANK3 haploinsufficiency alone is sufficient to increase risk. These findings also suggest that patients with SHANK3 mutations are overrepresented among individuals with PMS with neuropsychiatric decompensation or loss of skills. Whereas the proportion of patients with SHANK3 variants in the PMS International Registry (which gathers genetic and clinical data from affected individuals around the world) is $8.6 \%$ (47 out of 546 with a genetically confirmed diagnosis), it rises to $25 \%$ (14 of 56) among the cases reviewed here (Fisher's exact test, $p$ $=0.00057)$. This could be related to the fact that some individuals with SHANK3 mutations or small deletions develop phrase speech and can have less severe cognitive and motor deficits compared to individuals with large 22 q13.3 deletions, making it easier to recognize the psychiatric disorders and loss of skills. Alternatively, the higher level of functioning could render them more vulnerable to environmental and medical stressors. The mechanisms through which reduced expression of SHANK3 is associated with neuropsychiatric decompensation and loss of skills are unclear.

\section{Predisposing and precipitating factors}

In several patients, extensive neurologic and metabolic investigations were non-diagnostic. In the majority of cases, no apparent cause could be identified; in others, the symptoms appeared after acute infections (P22, P52,
P39, P52, P56), or presumably stressful environmental changes, such as being transferred to a new residential institution in five individuals (P13, P14, P33, P36, P37), or an institutional reorganization in another (P45). In three cases, the neurologic deterioration appears to have been related either to an increase in seizures, despite treatment (P20), or following a severe status epilepticus (P28, P47). In one individual (P10), the cognitive and physical deterioration appears to be secondary to metachromatic leukodystrophy [25], an autosomal recessive disorder characterized by progressive demyelination of peripheral and central nervous systems and caused by mutations in the arylsulfatase A (ARSA) gene on chromosome 22q13.33. Patients with deletions extending proximal to SHANK3 have one missing copy of ARSA and may develop metachromatic leukodystrophy in the presence of a pathogenic mutation in the remaining ARSA allele. However, the loss of both copies of the ARSA gene would be a rare event, expected in about 1/ 100-1/200 patients with PMS and a deletion involving ARSA (based on the estimated carrier frequency of ARSA mutations) [52]. Despite this expected frequency, there are only a handful of cases reported in the literature, and we know of no diagnosed cases in the PMS Foundation or national PMS associations. Therefore, metachromatic leukodystrophy is not expected to be a significant etiological factor in most patients with PMS exhibiting a regression phenotype, although the possibility that this disorder may be currently underdiagnosed cannot be excluded. Another slowly progressive autosomal recessive neurological disorder affecting white matter and causing progressive gait, fine motor, and cognitive disturbance, megalencephalic leukoencephalopathy with subcortical cysts due to biallelic MLC1 mutations, can also be unmasked by 22q13.33 deletions. This has been seen in one instance (unpublished patient of EBK); however, none of the neuroimaging described here was consistent with that disorder.

Five patients in this series (P3, P6, P11, P32, and P51), all with a ring chromosome 22 , developed neurofibromatosis type 2 associated tumors, diagnosed in adolescence or adulthood. Ring chromosomes are unstable during somatic mitoses and are prone to secondary rearrangements and subsequent loss. As a result, individuals with ring chromosome 22 often exhibit mosaic monosomy 22 . In the cells that lost the ring chromosome, a somatic mutation in the remaining NF2 gene results in tumor development; this is referred to as the two-hit model [60]. However, these tumors are not expected to be the cause of regression or neuropsychiatric decompensation in the majority of cases, since individuals with neurofibromatosis type 2 not associated with ring chromosome 22 and loss of SHANK3 do not exhibit an increased rate of psychopathology [61]. 
Anecdotal reports from families often describe acute events as frequent triggers, and when addressed, may lead to rapid resolution. As such, gastrointestinal disturbances (e.g., gastroesophageal reflux and constipation), urinary tract infections or retention, dental caries, ear infections, ovarian cysts, and uterine fibroids or tumors, should always be ruled out. Hormonal changes during the menstrual cycle may also contribute to psychiatric symptomatology and can sometimes be addressed by regulating menses using contraceptive medication.

\section{Similar clinical presentations in other neurodevelopmental disorders}

As older patients with genetic disorders are being diagnosed and assessed, we are gleaning insights into phenotypes throughout the lifespan. In both PMS and in other genetic disorders, neuropsychiatric deterioration appears to be more frequent than previously thought. In particular, regression, bipolar disorder, psychosis, and catatonia have been described in several other neurodevelopmental disorders associated with specific genetic defects. Kleefstra syndrome is caused by deletions or mutations of the EHMT1 gene, encoding a histone methyltransferase, and, like PMS, presents with ID, ASD, severe speech deficits, and hypotonia, in addition to distinctive facial features. At least six individuals with Kleefstra syndrome have been reported with severe behavioral regression developing during adolescence or adulthood, with periods of apathy and catatonia-like behaviors [62-64]. Individuals with Kleefstra syndrome also exhibit a high prevalence of depression, psychosis, and obsessivecompulsive disorder, with a general decline in functioning in all patients older than 18 years, usually preceded by severe sleep problems [65]. This regression has been hypothesized to be due to an often unrecognized psychotic episode, not treated adequately $[65,66]$, but certainly all these late onset symptoms could be the course of the disease and represent developmental changes in symptom susceptibility. 22q11.2 deletion syndrome (also known as velocardiofacial or DiGeorge syndrome) is also frequently associated with psychotic disorders, including a 25-fold increased risk of developing schizophrenia [67], typically emerging in late adolescence/early adulthood. The onset of psychosis is commonly preceded by cognitive decline [68]. Catatonia may be a relatively common finding in individuals with 22q11.2 deletion syndrome but often goes unrecognized [69]. In contrast, the prevalence of bipolar disorder does not appear to be increased compared to the general population [67].

Behavioral regression, bipolar disorder, psychosis, and catatonia have also been reported in patients with MBD5 haploinsufficiency (also known as autosomal dominant mental retardation 1 or 2 q23.1 deletion syndrome) [70, 71]; psychosis and catatonia are known to occur in a fraction of patients with Down syndrome [72-75]; and several instances of regression, psychosis/ schizophrenia, and bipolar disorder were described in Tatton-Brown-Rahman syndrome, an overgrowth ID syndrome caused by DNMT3A variants [76]. High rates of catatonia have also been reported in individuals with idiopathic autism $[77,78]$ as well as in those with ID [79], suggesting shared pathophysiological mechanisms. Further research is needed to study the prevalence of neuropsychiatric disorders across the lifespan in individuals with neurodevelopmental disorders of different etiologies and determine in which of these disorders neuropsychiatric disorders emerge more frequently than in the general population indicating an enhanced susceptibility. Possibly disorders with proven enhanced susceptibility will have overlapping molecular mechanisms that could provide clues to the underlying neuronal pathways promoting this susceptibility.

\section{Limitations}

The results from this review must be interpreted with caution due to several limitations. First, the cases reviewed may not be representative of the PMS population in its entirety. Due to ascertainment bias and underdiagnosis, it is impossible to estimate the overall prevalence of neuropsychiatric decompensation or loss of skills in PMS. Second, while clearly dramatic neuropsychiatric changes and loss of skills occur, the precise nature and extent of symptoms remain challenging to elucidate because many reports have limited descriptions of the subjects. While other reports present a more complete clinical evaluation, descriptions are mainly retrospective in nature. In particular, as noted, details about loss of skills and "regression" in most of the case reports do not clarify baseline levels of acquired skills or time course after skill loss. Likewise, psychotic symptoms were mentioned often in reports but too few details were available to reliably make the diagnosis of a primary psychotic disorder in most cases. In addition, it is challenging to establish a diagnosis in many cases based on the paucity of details provided in some of the original case reports and the review nature of our study design. Finally, regarding treatment, the number of patients receiving a given treatment was very limited and different doses and durations of treatment were applied. Treatment responses were also not assessed using standardized or validated measures. As such, insufficient data were available to draw firm conclusions about treatment themes. However, ongoing work is dedicated to establishing formal consensus treatment guidelines based on available evidence from the literature and expert clinician experience. 


\section{Conclusions}

In conclusion, the need for more systematic follow-up of the patients with PMS is crucial to facilitate our knowledge of disease progression but also, and more importantly, to optimize patient management. Indeed, it is evident that clinicians and caretakers need to be vigilant for loss of skills and neuropsychiatric changes in adolescents and adults with PMS, including the development of bipolar disorder and catatonia. The possibility of progressive neurological disorders needs to be considered, particularly in patients with 22q13 deletions that may unmask a recessive mutation. As successful interventions are identified, these approaches should become a part of the management of PMS. Until such time that formal consensus treatment guidelines are established, results from this review suggest that antidepressants and antipsychotic medications should be used with caution in PMS. And since loss of SHANK3 alone is sufficient to lead to susceptibility to loss of skills and neuropsychiatric decompensation, model systems should be studied over the lifespan and in the context of additional stressors to begin to dissect the pathobiology of regression in PMS and help in the development of novel interventions.

In an attempt to address some of the current treatment challenges highlighted in this review, the PMS Neuropsychiatric Consultation Group (PMS-NCG) was formed and aims to provide multidisciplinary consultation to geographically dispersed physicians, to support them in providing the best possible care to patients with PMS. This initiative utilizes an established model for knowledge dissemination called ECHO (https://echo.unm.edu/), which is based on video-conferencing case consultation with teams of experts and local providers meeting regularly to discuss case management. Information about clinical outcomes is also collected after ECHO consultations to inform future treatment guidelines. For more information, providers can visit the PMS Foundation website (https://www.pmsf.org/echo-project/).

\section{Abbreviations}

ASD: Autism spectrum disorder; ECT: Electroconvulsive therapy;

FISH: Fluorescence in situ hybridization; ID: Intellectual disability;

IQ: Intellectual quotient; PMS: Phelan-McDermid syndrome

\section{Acknowledgements}

We thank the Phelan-McDermid Syndrome International Registry from the Phelan-McDermid Syndrome Foundation for the comparison data on SHANK3 mutations.

\section{Authors' contributions}

CB conceived and designed the study; ED and CB performed the literature search and data collection; $A K, E D$, and $C B$ drafted the initial manuscript; $A K$, $E B K, J D B$, and $C B$ interpreted the findings and contributed to the writing of the manuscript. All authors read and approved the final manuscript.

\section{Funding}

ED was supported by a PhD fellowship from the French Ministry of Research. CB is a Research Director at INSERM. AK receives support from the National Institute of Neurological Disorders and Stroke (R01NS105845-01) and the New York Community Trust Jules and Ethel Klein Fund, and JDB and AK receive support from the Beatrice and Samuel A. Seaver Foundation. JDB, AK, and EB-K received support from an NIH Rare Disease Clinical Research Network grant (1 U54 NS092090-01).

Availability of data and materials

Not applicable

Ethics approval and consent to participate

Not applicable

\section{Consent for publication}

Not applicable

\section{Competing interests}

AK receives research support from AMO Pharma and consults to Ovid Therapeutics, Coronis Neurosciences, LabCorp, sema4, and Takeda. EBK has received funding from Seaside Therapeutics, Novartis, Roche, Alcobra, Neuren, Cydan, Fulcrum, GW, Neurotrope, Marinus, Zynerba, BioMarin, Ovid, Yamo, Acadia, Ionis, Ultragenyx, and Lumos Pharmaceuticals to consult on trial design or development strategies and/or conduct clinical studies in fragile $X$ syndrome or other neurologic, neurodevelopmental, or neurodegenerative disorders; from Vtesse/Sucampo/Mallinckrodt Pharmaceuticals to conduct clinical trials in Niemann-Pick disease type C; and from Asuragen Inc. to develop testing standards for FMR1 testing. All funding to EBK is directed to Rush University Medical Center in support of rare disease programs. JDB and Mount Sinai Hospital hold a shared patent for the use of insulin-like growth factor-1 in Phelan-McDermid syndrome; JDB consults with Coronis Neurosciences and sema4. AK, EBK, and CB are on the advisory board of the Phelan-McDermid Syndrome Foundation. ED declares that she has no competing interests.

\section{Author details}

${ }^{1}$ Seaver Autism Center for Research and Treatment, Icahn School of Medicine at Mount Sinai, New York, NY, USA. ${ }^{2}$ Department of Psychiatry, Icahn School of Medicine at Mount Sinai, New York, NY, USA. ${ }^{3}$ Department of Pediatrics, Icahn School of Medicine at Mount Sinai, New York, NY, USA. ${ }^{4}$ Friedman Brain Institute, Icahn School of Medicine at Mount Sinai, New York, NY, USA. ${ }^{5}$ Mindich Child Health and Development Institute, Icahn School of Medicine at Mount Sinai, New York, NY, USA. 'Sorbonne Université, INSERM, CNRS, Neuroscience Paris Seine, Institut de Biologie Paris Seine, Paris, France. ${ }^{7}$ Department of Pediatrics, Neurological Sciences, Biochemistry, Rush University Medical Center, Chicago, Illinois, USA. ${ }^{8}$ Department of Genetics and Genomic Sciences, Icahn School of Medicine at Mount Sinai, New York, NY, USA. ${ }^{9}$ Department of Neuroscience, Icahn School of Medicine at Mount Sinai, New York, NY, USA.

Received: 2 September 2019 Accepted: 9 October 2019

Published online: 24 December 2019

\section{References}

1. Kolevzon A, Angarita B, Bush L, Wang AT, Frank Y, Yang A, et al. PhelanMcDermid syndrome: a review of the literature and practice parameters for medical assessment and monitoring. J Neurodev Disord. 2014;6:39.

2. Durand CM, Betancur C, Boeckers TM, Bockmann J, Chaste P, Fauchereau F, et al. Mutations in the gene encoding the synaptic scaffolding protein SHANK3 are associated with autism spectrum disorders. Nat Genet. 2007;39: 25-7.

3. Bonaglia MC, Giorda R, Beri S, De Agostini C, Novara F, Fichera M, et al. Molecular mechanisms generating and stabilizing terminal 22q13 deletions in 44 subjects with Phelan/McDermid syndrome. PLoS Genet. 2011;7: e1002173.

4. De Rubeis S, Siper PM, Durkin A, Weissman J, Muratet F, Halpern D, et al. Delineation of the genetic and clinical spectrum of Phelan-McDermid syndrome caused by SHANK3 point mutations. Mol Autism. 2018;9:31. 
5. Gong $X$, Jiang $Y W$, Zhang $X, A n Y$, Zhang J, Wu Y, et al. High proportion of 22q13 deletions and SHANK3 mutations in Chinese patients with intellectual disability. PLoS One. 2012;7:e34739.

6. Betancur C, Buxbaum JD. SHANK3 haploinsufficiency: a "common" but underdiagnosed highly penetrant monogenic cause of autism spectrum disorders. Mol Autism. 2013:4:17.

7. Leblond CS, Nava C, Polge A, Gauthier J, Huguet G, Lumbroso S, et al. Metaanalysis of SHANK mutations in autism spectrum disorders: a gradient of severity in cognitive impairments. PLoS Genet. 2014;10:e1004580.

8. Samogy-Costa Cl, Varella-Branco E, Monfardini F, Ferraz H, Fock RA, Barbosa RHA, et al. A Brazilian cohort of individuals with Phelan-McDermid syndrome: genotype-phenotype correlation and identification of an atypical case. J Neurodev Disord. 2019:11:13.

9. Monteiro P, Feng G. SHANK proteins: roles at the synapse and in autism spectrum disorder. Nat Rev Neurosci. 2017;18:147-57.

10. Vucurovic K, Landais E, Delahaigue C, Eutrope J, Schneider A, Leroy C, et al. Bipolar affective disorder and early dementia onset in a male patient with SHANK3 deletion. Eur J Med Genet. 2012;55:625-9.

11. Denayer A, Van Esch H, de Ravel T, Frijns JP, Van Buggenhout G, Vogels A, et al. Neuropsychopathology in 7 patients with the 22 q13 deletion syndrome: presence of bipolar disorder and progressive loss of skills. Mol Syndromol. 2012;3:14-20.

12. Verhoeven WM, Egger Jl, Cohen-Snuijf R, Kant SG, de Leeuw N. PhelanMcDermid syndrome: clinical report of a 70-year-old woman. Am J Med Genet A. 2013;161A:158-61.

13. Anderlid BM, Schoumans J, Anneren G, Tapia-Paez I, Dumanski J, Blennow E, et al. FISH-mapping of a 100-kb terminal 22q13 deletion. Hum Genet. 2002; 110:439-43.

14. Stewart A, Richards BW. A note on a patient with a ring-22 chromosome identified by banding. J Ment Defic Res. 1976;20:95-8.

15. Reeve A, Shulman SA, Zimmerman AW, Cassidy SB. Methylphenidate therapy for aggression in a man with ring 22 chromosome. Report and literature review. Arch Neurol. 1985;42:69-72.

16. Arinami T, Kondo I, Hamaguchi H, Nakajima S. Multifocal meningiomas in a patient with a constitutional ring chromosome 22. J Med Genet. 1986;23:178-80.

17. Soorya L, Kolevzon A, Zweifach J, Lim T, Dobry Y, Schwartz L, et al. Prospective investigation of autism and genotype-phenotype correlations in 22q13 deletion syndrome and SHANK3 deficiency. Mol Autism. 2013:4:18

18. Macedoni-Luksic M, Krgovic D, Zagradisnik B, Kokalj-Vokac N. Deletion of the last exon of SHANK3 gene produces the full Phelan-McDermid phenotype: a case report. Gene. 2013;524:386-9.

19. Philippe A, Craus Y, Rio M, Bahi-Buisson N, Boddaert N, Malan V, et al. Case report: an unexpected link between partial deletion of the SHANK3 gene and Heller's dementia infantilis, a rare subtype of autism spectrum disorder. BMC Psychiatry. 2015;15:256.

20. Reierson G, Bernstein J, Froehlich-Santino W, Urban A, Purmann C, Berquist $\mathrm{S}$, et al. Characterizing regression in Phelan McDermid Syndrome (22q13 deletion syndrome). J Psychiatr Res. 2017;91:139-44.

21. Jeffries AR, Curran S, Elmslie F, Sharma A, Wenger S, Hummel M, et al. Molecular and phenotypic characterization of ring chromosome 22. Am J Med Genet A. 2005;137:139-47.

22. Millichap JG. Ring 22 syndrome and polyembolokoilomania. Ped Neurol Briefs. 1994:8:10.

23. Sovner R, Stone A, Fox C. Ring chromosome 22 and mood disorders. J Intellect Disabil Res. 1996;40:82-6.

24. Kehrer-Sawatzki H, Udart M, Krone W, Baden R, Fahsold R, Thomas G, et al. Mutational analysis and expression studies of the neurofibromatosis type 2 (NF2) gene in a patient with a ring chromosome 22 and NF2. Hum Genet. 1997;100:67-74.

25. Ishmael HA, Cataldi D, Begleiter ML, Pasztor LM, Dasouki MJ, Butler MG. Five new subjects with ring chromosome 22. Clin Genet. 2003;63:410-4.

26. Tsilchorozidou T, Menko FH, Lalloo F, Kidd A, De Silva R, Thomas H, et al. Constitutional rearrangements of chromosome 22 as a cause of neurofibromatosis 2. J Med Genet. 2004;41:529-34

27. Nawab K, Hussain I, Findlay L. Ring chromosome 22, mood disorder and sodium valproate (a case report). Brit J Dev Disabil. 2007;53:153-6.

28. Gauthier J, Champagne N, Lafreniere RG, Xiong L, Spiegelman D, Brustein E, et al. De novo mutations in the gene encoding the synaptic scaffolding protein SHANK3 in patients ascertained for schizophrenia. Proc Natl Acad Sci USA. 2010;107:7863-8.
29. Pasini A, D'Agati E, Casarelli L, Curatolo P. Dose-dependent effect of risperidone treatment in a case of 22q13.3 deletion syndrome. Brain Dev. 2010;32:425-7

30. Willemsen $\mathrm{MH}$, Rensen $\mathrm{JH}$, van Schrojenstein-Lantman de Valk HM, Hame BC, Kleefstra T. Adult phenotypes in Angelman- and Rett-like syndromes. Mol Syndromol. 2011;2:217-34

31. Verhoeven WM, Egger JI, Willemsen MH, de Leijer GJ, Kleefstra T. PhelanMcDermid syndrome in two adult brothers: atypical bipolar disorder as its psychopathological phenotype? Neuropsychiatr Dis Treat. 2012;8:175-9.

32. Egger II, Zwanenburg RJ, van Ravenswaaij-Arts CM, Kleefstra T, Verhoeven WM. Neuropsychological phenotype and psychopathology in seven adult patients with Phelan-McDermid syndrome: implications for treatment strategy. Genes Brain Behav. 2016;15:395-404.

33. Breckpot J, Vercruyssen M, Weyts E, Vandevoort S, D'Haenens G, Van Buggenhout $\mathrm{G}$, et al. Copy number variation analysis in adults with catatonia confirms haploinsufficiency of SHANK3 as a predisposing factor. Eur J Med Genet. 2016:59:436-43.

34. Smith JH, Smith VD, Philbrick KL, Kumar N. Catatonic disorder due to a general medical or psychiatric condition. J Neuropsychiatry Clin Neurosci. 2012;24:198-207.

35. Messias E, Kaley SN, McKelvey KD. Adult-onset psychosis and clinical genetics: a case of Phelan-McDermid syndrome. J Neuropsychiatry Clin Neurosci. 2013;25:E27.

36. McKelvey KD Jr, Trana CJ, Kelsay J, Sawyer J, Clothier J. Phelan-McDermid syndrome and cancer predisposition: The value of a karyotype. Am J Med Genet A. 2018;176:144-5.

37. Guilherme RS, Soares KC, Simioni M, Vieira TP, Gil-da-Silva-Lopes VL, Kim CA et al. Clinical, cytogenetic, and molecular characterization of six patients with ring chromosomes 22, including one with concomitant 22q11.2 deletion. Am J Med Genet A. 2014;164A:1659-65.

38. Serret S, Thummler S, Dor E, Vesperini S, Santos A, Askenazy F. Lithium as a rescue therapy for regression and catatonia features in two SHANK3 patients with autism spectrum disorder: case reports. BMC Psychiatry. 2015;15:107.

39. Fokstuen S, Makrythanasis P, Hammar E, Guipponi M, Ranza E, Varvagiannis $\mathrm{K}$, et al. Experience of a multidisciplinary task force with exome sequencing for Mendelian disorders. Hum Genomics. 2016;10:24.

40. Egger JIM, Verhoeven WMA, Groenendijk-Reijenga R, Kant SG. Phelan-McDermid syndrome due to SHANK3 mutation in an intellectually disabled adult male: successful treatment with lithium. BMJ Case Rep. 2017;2017:bcr-2017-220778.

41. Tabet AC, Rolland T, Ducloy M, Levy J, Buratti J, Mathieu A, et al. A framework to identify contributing genes in patients with Phelan-McDermid syndrome. NPJ Genom Med. 2017;2:32.

42. Ballesteros A, Rosero ÁS, Inchausti F, Manrique E, Sáiz H, Carlos C, et al. Clinical case: Phelan-McDermid and pharmacological management. Abstract V0081, 25th European Congress of Psychiatry, 2017. Eur Psychiatry:41S-S430

43. Lyons-Warren AM, Cheung SW, Holder JL Jr. Clinical reasoning: a common cause for Phelan-McDermid syndrome and neurofibromatosis type 2: One ring to bind them. Neurology. 2017:89:e205-9.

44. Kildahl AN, Berg LK, Nilssen ALE, Bjørgo K, Rødningen O, Helverschou SB. Psychiatric assessment in Phelan-McDermid Syndrome (22q13 deletion syndrome). J Intellect Dev Disabil. 2018. https://doi.org/10.3109/13668250. 2018.1440135.

45. Jungova P, Cumova A, Kramarova V, Lisyova J, Durina P, Chandoga J, et al. Phelan-McDermid syndrome in adult patient with atypical bipolar psychosis repeatedly triggered by febrility. Neurocase. 2018;24:227-30.

46. Richards BW, Rundle AT, Hatton WM, Stewart A. G-group ring chromosome in a mentally subnormal girl. J Ment Defic Res. 1971;15:61-72.

47. Kondo I, Hamaguchi H, Nakajima S, Haneda T. A cytogenetic survey of 449 patients in a Japanese institution for the mentally retarded. Clin Genet. 1980;17:177-82.

48. Anderlid BM, Schoumans J, Anneren G, Sahlen S, Kyllerman M, Vujic M, et al Subtelomeric rearrangements detected in patients with idiopathic mental retardation. Am J Med Genet. 2002;107:275-84.

49. Darville H, Poulet A, Rodet-Amsellem F, Chatrousse L, Pernelle J, Boissart C, et al. Human pluripotent stem cell-derived cortical neurons for high throughput medication screening in autism: a proof of concept study in SHANK3 haploinsufficiency syndrome. EBioMedicine. 2016;9:293-305.

50. American Psychiatric Association. Diagnostic and statistical manual of mental disorders, 5th edition, text revision. Washington, DC: American Psychiatric Association; 2013 
51. Barnhill J, Cooper SA, Fletcher RJ, editors. Diagnostic manual-intellectual disability 2 (DM-ID): a textbook of diagnosis of mental disorders in persons with intellectual disability. Second ed.: NADD; 2017.

52. Gomez-Ospina N. Arylsulfatase A deficiency. In: Adam MP, Ardinger $\mathrm{HH}$, Pagon RA, Wallace SE, Bean LJH, Stephens K, et al., editors. GeneReviews. Seattle (WA): University of Washington, Seattle; 2006 [updated 2017 Dec 14]

53. Goodwin GM, Haddad PM, Ferrier IN, Aronson JK, Barnes T, Cipriani A, et al. Evidence-based guidelines for treating bipolar disorder: revised third edition recommendations from the British Association for Psychopharmacology. J Psychopharmacol. 2016;30:495-553.

54. Verhoeven WMA, Egger JIM, de Leeuw N. A longitudinal perspective on the pharmacotherapy of 24 adult patients with Phelan McDermid syndrome. Eur J Med Genet. 2019 (advance online publication).

55. Dhossche DM, Wachtel LE. Catatonia is hidden in plain sight among different pediatric disorders: a review article. Pediatr Neurol. 2010;43:307-15.

56. Phelan K, Rogers RC, Boccuto L. Phelan-McDermid Syndrome. In: Adam MP, Ardinger HH, Pagon RA, Wallace SE, Bean LH, Stephens K, et al, editors. GeneReviews. Seattle (WA): University of Washington, Seattle; 2005 [updated 2018 Jun 7].

57. Cohen D, Flament M, Dubos PF, Basquin M. Case series: catatonic syndrome in young people. J Am Acad Child Adolesc Psychiatry. 1999;38:1040-6.

58. Takaoka K, Takata T. Catatonia in childhood and adolescence. Psychiatry Clin Neurosci. 2003:57:129-37.

59. Fink M, Taylor MA, Ghaziuddin N. Catatonia in autistic spectrum disorders: a medical treatment algorithm. Int Rev Neurobiol. 2006;72:233-44.

60. Zirn B, Arning L, Bartels I, Shoukier M, Hoffjan S, Neubauer B, et al. Ring chromosome 22 and neurofibromatosis type II: proof of two-hit model for the loss of the NF2 gene in the development of meningioma. Clin Genet. 2012;81:82-7.

61. Evans DG. Neurofibromatosis 2. In: Adam MP, Ardinger HH, Pagon RA, Wallace SE, Bean LJH, Stephens K, et al., editors. GeneReviews. Seattle (WA): University of Washington, Seattle; 1998 [updated 2018 Mar 15].

62. Verhoeven WM, Kleefstra T, Egger II. Behavioral phenotype in the $9 q$ subtelomeric deletion syndrome: a report about two adult patients. Am J Med Genet B Neuropsychiatr Genet. 2010;153B:536-41.

63. Verhoeven WM, Egger II, Vermeulen K, van de Warrenburg BP, Kleefstra T. Kleefstra syndrome in three adult patients: further delineation of the behavioral and neurological phenotype shows aspects of a neurodegenerative course. Am J Med Genet A. 2011;155A:2409-15.

64. Mitra AK, Dodge J, Van Ness J, Sokeye I, Van Ness B. A de novo splice site mutation in EHMT1 resulting in Kleefstra syndrome with pharmacogenomics screening and behavior therapy for regressive behaviors. Mol Genet Genomic Med. 2017;5:130-40.

65. Vermeulen $\mathrm{K}$, de Boer A, Janzing JGE, Koolen DA, Ockeloen CW, Willemsen $\mathrm{MH}$, et al. Adaptive and maladaptive functioning in Kleefstra syndrome compared to other rare genetic disorders with intellectual disabilities. Am J Med Genet A. 2017;173:1821-30.

66. Vermeulen K, Staal WG, Janzing JG, van Bokhoven H, Egger JIM, Kleefstra T. Sleep disturbance as a precursor of severe regression in Kleefstra syndrome suggests a need for firm and rapid pharmacological treatment. Clin Neuropharmacol. 2017:40:185-8.

67. Schneider M, Debbane M, Bassett AS, Chow EW, Fung WL, van den Bree $M$, et al. Psychiatric disorders from childhood to adulthood in 22q11.2 deletion syndrome: results from the International Consortium on Brain and Behavior in 22q11.2 Deletion Syndrome. Am J Psychiatry. 2014;171:627-39.

68. Vorstman JA, Breetvelt EJ, Duijff SN, Eliez S, Schneider M, Jalbrzikowski M, et al. Cognitive decline preceding the onset of psychosis in patients with 22q11.2 deletion syndrome. JAMA Psychiatry. 2015;72:377-85.

69. Faedda GL, Wachtel LE, Higgins AM, Shprintzen RJ. Catatonia in an adolescent with velo-cardio-facial syndrome. Am J Med Genet A. 2015;167A:2150-3.

70. Hodge JC, Mitchell E, Pillalamarri V, Toler TL, Bartel F, Kearney HM, et al. Disruption of MBD5 contributes to a spectrum of psychopathology and neurodevelopmental abnormalities. Mol Psychiatry. 2014;19:368-79.

71. Verhoeven W, Egger J, Kipp J, Verheul-Aan de Wiel J, Ockeloen C, Kleefstra $T$, et al. A novel MBD5 mutation in an intellectually disabled adult female patient with epilepsy: Suggestive of early onset dementia? Mol Genet Genomic Med. 2019;7:e849.

72. Dykens EM, Shah B, Davis B, Baker C, Fife T, Fitzpatrick J. Psychiatric disorders in adolescents and young adults with Down syndrome and other intellectual disabilities. J Neurodev Disord. 2015;7:9.
73. Ghaziuddin N, Nassiri A, Miles JH. Catatonia in Down syndrome; a treatable cause of regression. Neuropsychiatr Dis Treat. 2015;11:941-9.

74. Jacobs J, Schwartz A, McDougle CJ, Skotko BG. Rapid clinical deterioration in an individual with Down syndrome. Am J Med Genet A. 2016;170:1899-902.

75. Jap SN, Ghaziuddin N. Catatonia among adolescents with Down syndrome: a review and 2 case reports. J ECT. 2011;27:334-7.

76. Tatton-Brown K, Zachariou A, Loveday C, Renwick A, Mahamdallie S, Aksglaede $L$, et al. The Tatton-Brown-Rahman syndrome: A clinical study of 55 individuals with de novo constitutive DNMT3A variants. Wellcome Open Res. 2018;3:46.

77. Dhossche DM. Decalogue of catatonia in autism spectrum disorders. Front Psychiatry. 2014;5:157.

78. Wachtel LE. The multiple faces of catatonia in autism spectrum disorders: descriptive clinical experience of 22 patients over 12 years. Eur Child Adolesc Psychiatry. 2019:28:471-80.

79. Ghaziuddin N, Dhossche D, Marcotte K. Retrospective chart review of catatonia in child and adolescent psychiatric patients. Acta Psychiatr Scand. 2012;125:33-8.

\section{Publisher's Note}

Springer Nature remains neutral with regard to jurisdictional claims in published maps and institutional affiliations.
Ready to submit your research? Choose BMC and benefit from:

- fast, convenient online submission

- thorough peer review by experienced researchers in your field

- rapid publication on acceptance

- support for research data, including large and complex data types

- gold Open Access which fosters wider collaboration and increased citations

- maximum visibility for your research: over $100 \mathrm{M}$ website views per year

At BMC, research is always in progress.

Learn more biomedcentral.com/submissions 